\title{
Transactions
}

\section{Variation in the biomolecular interactions of nickel(II) hydrazone complexes upon tuning the hydrazide fragment $\uparrow$}

\author{
Paramasivam Krishnamoorthy, ${ }^{a}$ Palanisamy Sathyadevi, ${ }^{a}$ Rachel R. Butorac, ${ }^{b}$ Alan H. Cowley, ${ }^{b}$ \\ Nattamai S. P. Bhuvanesh ${ }^{c}$ and Nallasamy Dharmaraj ${ }^{a}$
}

Received 18th January 2012, Accepted 20th March 2012
DOI: 10.1039/c2dt30121k

Three new bivalent nickel hydrazone complexes have been synthesised from the reactions of $\left[\mathrm{NiCl}_{2}\left(\mathrm{PPh}_{3}\right)_{2}\right]$ with $\mathrm{H}_{2} \mathrm{~L}\{\mathrm{~L}=$ dianion of the hydrazones derived from the condensation of $o$-hydroxynaphthaldehyde with furoic acid hydrazide $\left(\mathrm{H}_{2} \mathrm{~L}^{1}\right)(\mathbf{1})$ /thiophene-2-acid hydrazide $\left(\mathrm{H}_{2} \mathrm{~L}^{2}\right)$ (2)/isonicotinic acid hydrazide $\left.\left(\mathrm{H}_{2} \mathrm{~L}^{3}\right)(\mathbf{3})\right\}$ and formulated as $\left[\mathrm{Ni}\left(\mathrm{L}^{1}\right)\left(\mathrm{PPh}_{3}\right)\right](4)$, $\left[\mathrm{Ni}\left(\mathrm{L}^{2}\right)\left(\mathrm{PPh}_{3}\right)\right](\mathbf{5})$ and $\left[\mathrm{Ni}\left(\mathrm{L}^{3}\right)\left(\mathrm{PPh}_{3}\right)\right](6)$. Structural characterization of these compounds 4-6 were accomplished by using various physico-chemical techniques. Single crystal X-ray diffraction data of complexes $\mathbf{4}$ and $\mathbf{5}$ proved their distorted square planar geometry. In order to ascertain the potential of the above synthesised compounds towards biomolecular interactions, additional experiments involving interaction with calf thymus DNA (CT DNA) and bovine serum albumin (BSA) were carried out. All the ligands and corresponding nickel(II) chelates have been screened for their scavenging effect towards $\mathrm{O}_{2}{ }^{-}, \mathrm{OH}$ and $\mathrm{NO}$ radicals. The efficiency of complexes 4-6 to arrest the growth of HeLa, HepG-2 and A431 tumour cell lines has been studied along with the cell viability test against the non-cancerous NIH 3T3 cells under in vitro conditions.

\section{Introduction}

The bioinorganic chemistry of nickel has been rapidly expanded due to the increasing interest in nickel complexes ${ }^{1-3}$ that have been shown to act as antiepileptic, anticonvulsant agents or vitamins or have shown antibacterial, antifungal, antimicrobial and anticancer/antiproliferative activity. ${ }^{4-16}$ Hydrazone ligands create an environment similar to the one present in biological systems usually by making coordination through oxygen and nitrogen atoms. Various important properties of carbonic acid hydrazides, along with their applications in medicine and analytical chemistry, have led to increased interest in their complexation characteristics with transition metal ions. ${ }^{17}$ The hydrazone unit offers a

\footnotetext{
${ }^{a}$ Department of Chemistry, Bharathiar University, Coimbatore - 641 046, India.E-mail: dharmaraj@buc.edu.in; Fax:+91422 2422387; Tel: +914222428316

${ }^{b}$ Department of Chemistry and Biochemistry, University of Texas at Austin, Austin, Texas 78712, U.S.A

${ }^{c}$ Department of Chemistry, Texas A\&M University, College Station, TX 77843, U.S.A

$\dagger$ Electronic supplementary information (ESI) available: crystal packing diagram of the unit cell of complexes 4 and 5 (Fig. S1 and S2), electronic absorption spectra of compounds 1-5 with DNA (Fig. S3 and S4), emission spectra of DNA-EB in the presence of compounds 1-5 (Fig. S5 and S6), emission spectra of binding of compounds 1-5 with BSA (Fig. S7 and S8), synchronous spectra $(\Delta \lambda=15$ and $60 \mathrm{~nm})$ of binding of compounds 1-5 with BSA (Fig. S9 and S10), \% cell inhibition of NIH 3T3, HeLa, HepG-2 and A431 cell lines by nickel hydrazones 4, 5 and 6 (Fig. S11). CCDC reference numbers 796261 and 851587 complexes $\mathbf{4}$ and 5. For ESI and crystallographic data in CIF or other electronic format see DOI: 10.1039/c2dt30121k
}

number of attractive features such as the degree of rigidity, a conjugated $\pi$-system and an $\mathrm{NH}$ unit that readily participates in hydrogen bonding and may be a site of protonation-deprotonation. It is well established that the formation of metal complexes plays an important role to enhance the biological activity of free hydrazones. ${ }^{18}$

Due to the key role of DNA in cell life and pathological processes, the design of specific chemical nucleases, DNA probes and alkylating agents is an important research area for the development of new therapeutic agents and tools in biochemistry. Hence, the interaction of small molecules with DNA has attracted in particular a great deal of attention. The two most common non-covalent binding motifs for such systems are the groove binding and intercalating modes. Many therapeutic agents, particularly anticancer drugs, are known to bind DNA via either of these motifs and the possibility of gene modulation by specific sequence binding of small molecules to DNA has also been explored. The interaction of $\mathrm{Ni}$ (II) complexes with DNA has been mainly dependent on the structure of the ligand exhibiting intercalative behavior ${ }^{19-23}$ and/or DNA cleavage ability. ${ }^{24,25}$

Serum albumin is the major soluble protein constituent in the circulatory system of a wide variety of organisms and it has the ability to reversibly bind to a large variety of endogenous and exogenous ligands such as fatty acids, drugs, and metal ions in the bloodstream. ${ }^{26,27}$ The drug-protein complex not only strongly affected the absorption, distribution, metabolism and excretion properties of drugs, but also influenced the drug stability and toxicity during the chemotherapeutic process. Therefore, knowledge of the mechanism of interaction between the selected 
drug and protein has become very vital to the design of several new drugs with improved potential. ${ }^{28,29}$ In the current work, the authors have chosen bovine serum albumin (BSA) as a model protein to investigate its interaction with the newly synthesised nickel hydrazone chelates 4-6.

The present study was undertaken to establish the bioinorganic potential of the titled compounds for nucleic acid interactions, protein interactions, free radical scavenging and cytotoxicity. The effect of changing the hydrazide moieties of hydrazones upon the above mentioned properties were also discussed in line with the electronegativity of the hetero atoms as well as the size of heterocyclic ring of hydrazides.

\section{Experimental section}

\section{Materials and reagents}

Reagent grade chemicals $\mathrm{NiCl}_{2} \cdot 6 \mathrm{H}_{2} \mathrm{O}$, triphenylphosphine, $o$-hydroxynaphthaldehyde, furoic acid hydrazide, thiophene-2carboxylic acid hydrazide and isonicotinic acid hydrazide were purchased from Sigma-Aldrich and used as received. Calf thymus DNA (CT DNA) and bovine serum albumin (BSA) were purchased from Himedia Company. The human cervical cancer cell line (HeLa), human skin cancer cell line (A431), HepG2 (human liver hepatocellular carcinoma cells) and NIH 3T3 mouse embryonic fibroblasts was obtained from National Centre for Cell Science (NCCS), Pune, India. All the other chemicals and reagents used for DNA binding, protein binding, antioxidant, cytotoxicity assays were of high quality and available from reputed suppliers.

Synthesis of ligands (1-3) and corresponding nickel hydrazone complexes (4-6). Chemical reactions involved in the synthesis of hydrazone ligands and corresponding nickel complexes were given in Scheme 1.

Synthesis of nickel precursor complex. The precursor metal complex $\left[\mathrm{NiCl}_{2}\left(\mathrm{PPh}_{3}\right)_{2}\right]$ was prepared according to the literature method. $^{30}$
Synthesis of furan-2-carboxylic acid (3-hydroxy-naphthalen-2ylmethylene)-hydrazide $\left(\mathbf{H}_{2} \mathbf{L}^{\mathbf{1}}\right)$ (1). The ligand furan-2-carboxylic acid (3-hydroxy-naphthalen-2-ylmethylene)-hydrazide (1) was prepared by refluxing an equimolar mixture of $o$-hydroxynaphthaldehyde $(0.172 \mathrm{~g} ; 1 \mathrm{mM})$ and furoic acid hydrazide $(0.126 \mathrm{~g} ; 1 \mathrm{mM})$ in $50 \mathrm{~mL}$ of absolute ethanol for $8 \mathrm{~h}$ as given in Scheme 1. The reaction mixture was cooled to room temperature and the solid obtained was filtered, washed several times with distilled water and recrystallized from $\mathrm{EtOH}$ to afford the ligand 1 in pure form with $83 \%$ yield. Mp $131-133{ }^{\circ} \mathrm{C}$. Anal. Found: $\mathrm{C}, 67.9 ; \mathrm{H}, 4.0 ; \mathrm{N}, 9.6 \%$. Calc. for $\mathrm{C}_{16} \mathrm{H}_{12} \mathrm{~N}_{2} \mathrm{O}_{3}$ $($ Mol. wt $=280.278): \mathrm{C}, 68.6 ; \mathrm{H}, 4.3 ; \mathrm{N}, 10.0 \%$. ESI-MS (MeOH-buffer): Found $m / z=280(\mathrm{M}+\mathrm{H})$ (calculated $\mathrm{m} / \mathrm{z}=$ 279 for $\left.\mathrm{M}^{+}\right)$. Selected IR bands $\left(v_{\max } / \mathrm{cm}^{-1}\right)$ : 3440 (phenolic, $\mathrm{OH})$; $3215(\mathrm{NH}) ; 1640(\mathrm{C}=\mathrm{O}) ; 1604(\mathrm{C}=\mathrm{N}) ; 1016(\mathrm{~N}-\mathrm{N})$; 1240 (phenolic, C-OH). $\delta_{\mathrm{H}}\left(500 \mathrm{MHz} ; \mathrm{DMSO}-\mathrm{d}_{6} ; \mathrm{Me}_{4} \mathrm{Si}\right)$ : $12.24(1 \mathrm{H}, \mathrm{s}, \mathrm{OH}) ; 9.43(1 \mathrm{H}, \mathrm{s}, \mathrm{NH}) ; 8.05(1 \mathrm{H}, \mathrm{s}, \mathrm{CH}=\mathrm{N})$; 7.86-6.64 (9H, m, Ar-H).

Synthesis of thiophene-2-carboxylic acid (3-hydroxy-naphthalen-2ylmethylene)-hydrazide $\left(\mathrm{H}_{2} \mathbf{L}^{\mathbf{2}}\right)$ (2). Ligand 2 was prepared by a procedure similar to the one described above utilizing $o$-hydroxynaphthaldehyde $(0.172 \mathrm{~g} ; 1 \mathrm{mM})$ and thiophene-2carboxylic acid hydrazide $(0.142 \mathrm{~g} ; 1 \mathrm{mM})$ (Scheme 1$). \mathrm{Mp}$ $138-140{ }^{\circ} \mathrm{C}$. Anal. Found: C, 64.45; H, 3.62; N, 8.97; S, 10.05\%. Calc. for $\mathrm{C}_{16} \mathrm{H}_{12} \mathrm{~N}_{2} \mathrm{O}_{2} \mathrm{~S}$ (Mol. wt = 296.343): C, 64.85; H, 4.08; N, 9.45, S, 10.82\%. ESI-MS (MeOH-buffer): Found $m / z=296(\mathrm{M}+\mathrm{H})$ (calculated $m / z=295$ for $\left.\mathrm{M}^{+}\right)$. Selected IR bands $\left(v_{\max } / \mathrm{cm}^{-1}\right): 3405$ (phenolic, $\left.\mathrm{OH}\right) ; 3225(\mathrm{NH}) ; 1634$ $(\mathrm{C}=\mathrm{O}) ; 1586(\mathrm{C}=\mathrm{N}) ; 1037(\mathrm{~N}-\mathrm{N}) ; 1282$ (phenolic, $\mathrm{C}-\mathrm{OH}) . \delta_{\mathrm{H}}$ (500 MHz; DMSO-d 6 ; $\left.\mathrm{Me}_{4} \mathrm{Si}\right): 13.18(1 \mathrm{H}, \mathrm{s}, \mathrm{OH}) ; 9.28(1 \mathrm{H}, \mathrm{s}$, $\mathrm{NH}) ; 8.34(1 \mathrm{H}, \mathrm{s}, \mathrm{CH}=\mathrm{N}) ; 7.85-7.17(9 \mathrm{H}, \mathrm{m}, \mathrm{Ar}-\mathrm{H})$.

Synthesis of isonicotinic acid (3-hydroxy-naphthalen-2ylmethylene)-hydrazide $\left(\mathbf{H}_{2} \mathbf{L}^{3}\right)$ (3). Ligand 3 was prepared using a similar procedure as described above with $o$-hydroxynaphthaldehyde $(0.172 \mathrm{~g} ; 1 \mathrm{mM})$ and isonicotinic acid hydrazide (0.137 $\mathrm{g} ; 1 \mathrm{mM}$ ) as suitable reactants (Scheme 1). Mp $150-153{ }^{\circ} \mathrm{C}$. Anal. Found: C, 69.93; H, 4.32; N, 14. 27\%. Calc. for $\mathrm{C}_{17} \mathrm{H}_{13} \mathrm{~N}_{3} \mathrm{O}_{2}$ (Mol. wt = 291.304): $\mathrm{C}, 70.09 ; \mathrm{H}, 4.50 ; \mathrm{N}$, 14.42\%. ESI-MS (MeOH-buffer): Found $m / z=291(\mathrm{M}+\mathrm{H})$

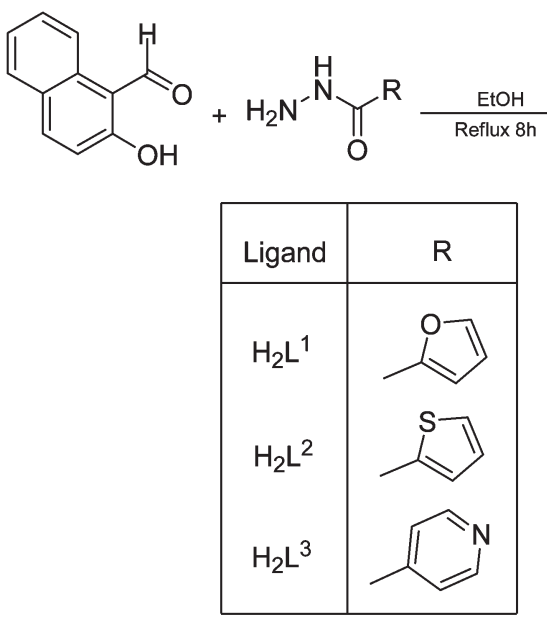

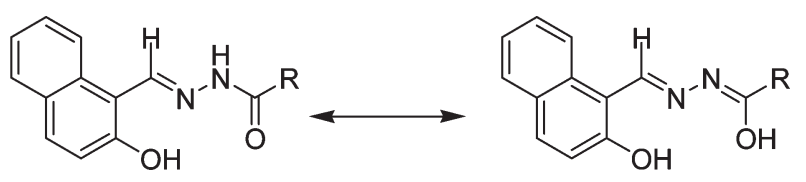

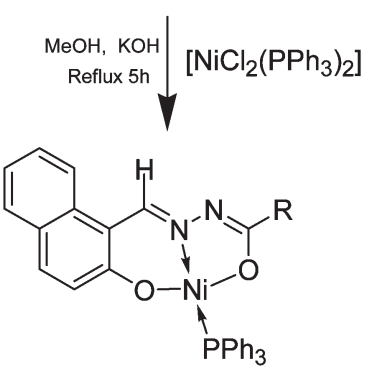

Scheme 1 
(calculated $\mathrm{m} / z=290$ for $\left.\mathrm{M}^{+}\right)$. Selected IR bands $\left(v_{\max } / \mathrm{cm}^{-1}\right)$ : 3442 (phenolic, $\mathrm{OH}) ; 3212(\mathrm{NH}) ; 1640(\mathrm{C}=\mathrm{O}) ; 1606(\mathrm{C}=\mathrm{N})$; $1017(\mathrm{~N}-\mathrm{N}) ; 1241$ (phenolic, $\mathrm{C}-\mathrm{OH}) . \delta_{\mathrm{H}}(500 \mathrm{MHz}$; DMSO-d 6 ; $\left.\mathrm{Me}_{4} \mathrm{Si}\right): 12.64(1 \mathrm{H}, \mathrm{s}, \mathrm{OH}) ; 9.51(1 \mathrm{H}, \mathrm{s}, \mathrm{NH}) ; 8.23(1 \mathrm{H}, \mathrm{s}$, $\mathrm{CH}=\mathrm{N}) ; 8.01-6.75(10 \mathrm{H}, \mathrm{m}, \mathrm{Ar}-\mathrm{H})$.

Synthesis of new nickel(II) hydrazone complex $\left[\mathrm{Ni}\left(\mathrm{L}^{1}\right)\left(\mathbf{P P h}_{3}\right)\right]$ (4). Complex 4 was synthesised by refluxing a methanolic solution of $\left[\mathrm{NiCl}_{2}\left(\mathrm{PPh}_{3}\right)_{2}\right](0.653 \mathrm{~g} ; 1 \mathrm{mM})$ and the ligand $\mathbf{1}$ $(0.280 \mathrm{~g} ; 1 \mathrm{mM})(40 \mathrm{~mL})$ in the presence of $\mathrm{KOH}$ (Scheme 1) for $5 \mathrm{~h}$. After cooling the reaction mixture to room temperature, the precipitate formed was filtered, washed with methanol and dried in vacuo. The purity of the complex was checked by TLC following which tetragonal shaped crystals of complex $\mathbf{4}$ suitable for single-crystal X-ray diffraction studies were obtained by recrystallisation in dichloromethane. Yield: $74 \%$. Color: dark red, mp $257-259^{\circ} \mathrm{C}$. Anal. Found: $\mathrm{C}, 67.46 ; \mathrm{H}, 3.81 ; \mathrm{N}, 4.02 \%$. Calc. for $\mathrm{NiC}_{34} \mathrm{H}_{25} \mathrm{~N}_{2} \mathrm{O}_{3} \mathrm{P}$ (Mol. wt $\left.=599.24\right)$ : C, 68.15; H, 4.21; N, 4.67\%. ESI-MS (MeOH-buffer): Found $m / z=599$ $(\mathrm{M}+\mathrm{H})$ (calculated $m / z=598$ for $\mathrm{M}^{+}$). Selected IR bands $\left(v_{\max } / \mathrm{cm}^{-1}\right): 1614 \& 1519(\mathrm{C}=\mathrm{N}-\mathrm{N}=\mathrm{C}) ; 1360$ (phenolic, $\mathrm{C}-\mathrm{O}) ; 1320$ (enolic, $\mathrm{C}-\mathrm{O}) ; 1034(\mathrm{~N}-\mathrm{N}) . \delta_{\mathrm{H}}(500 \mathrm{MHz}$; DMSO$\left.\mathrm{d}_{6} ; \mathrm{Me}_{4} \mathrm{Si}\right): 8.16(1 \mathrm{H}, \mathrm{s}, \mathrm{HC}=\mathrm{N}) ; 7.87-6.37(24 \mathrm{H}, \mathrm{m}, \mathrm{Ar}-\mathrm{H})$.

Synthesis of $\left[\mathbf{N i}\left(\mathrm{L}^{2}\right)\left(\mathbf{P P h}_{3}\right)\right]$ (5). Complex $\mathbf{5}$ was prepared by a procedure similar to that given in the case of $\mathbf{4}$, from $\left[\mathrm{NiCl}_{2}\left(\mathrm{PPh}_{3}\right)_{2}\right](0.653 \mathrm{~g} ; 1 \mathrm{mM})$ and ligand $2(0.296 \mathrm{~g} ; 1 \mathrm{mM})$ as reactants (Scheme 1). The purity of the complex was checked by TLC following which tetragonal shaped crystals of complex 5 suitable for single-crystal X-ray diffraction studies were obtained by recrystallisation in dichloromethane. Yield: $75 \%$. Color: dark red, $\mathrm{mp} 248-251{ }^{\circ} \mathrm{C}$. Anal. Found: C, 65.94; H, 3.97; N, 4.06, S, 4.86\%. Calc. for $\mathrm{NiC}_{34} \mathrm{H}_{25} \mathrm{~N}_{2} \mathrm{O}_{2} \mathrm{PS}$ (mol. wt $=$ 615.30): C, 66.37; H, 4.10; N, 4.55; S, 5.21\%. ESI-MS (MeOHbuffer): Found $m / z=615(\mathrm{M}+\mathrm{H})$ (calculated $m / z=614$ for $\left.\mathrm{M}^{+}\right)$. Selected IR bands $\left(v_{\max } / \mathrm{cm}^{-1}\right): 1612 \& 1527(\mathrm{C}=\mathrm{N}-$ $\mathrm{N}=\mathrm{C}$ ); 1398 (phenolic, $\mathrm{C}-\mathrm{O}$ ); 1328 (enolic, $\mathrm{C}-\mathrm{O}$ ); 1094 $(\mathrm{N}-\mathrm{N}) . \delta_{\mathrm{H}}\left(500 \mathrm{MHz} ; \mathrm{DMSO}-\mathrm{d}_{6} ; \mathrm{Me}_{4} \mathrm{Si}\right): 9.23(1 \mathrm{H}, \mathrm{s}, \mathrm{HC}=\mathrm{N})$; 7.88-6.60 (24H, m, Ar-H).

Synthesis of $\left[\mathbf{N i}\left(\mathbf{L}^{3}\right)\left(\mathbf{P P h}_{3}\right)\right]$ (6). Complex $\mathbf{6}$ was prepared by a procedure similar to that given in the case of $\mathbf{5}$, from $\left[\mathrm{NiCl}_{2}\left(\mathrm{PPh}_{3}\right)_{2}\right](0.653 \mathrm{~g} ; 1 \mathrm{mM})$ and ligand $3(0.291 \mathrm{~g} ; 1 \mathrm{mM})$ as reactants (Scheme 1). Attempts made to grow suitable crystals of complex $\mathbf{6}$ suitable for single crystal XRD studies were unsuccessful. Yield: $73 \%$. Color: dark red, $\mathrm{mp} 260-263{ }^{\circ} \mathrm{C}$. Anal. Found: C, 68.14; H, 3.97; N, 6.02\%. Calc. for $\mathrm{NiC}_{35} \mathrm{H}_{26} \mathrm{~N}_{3} \mathrm{O}_{2} \mathrm{P}$ (mol. wt $=610.267): \mathrm{C}, 68.88 ; \mathrm{H}, 4.29 ; \mathrm{N}, 6.89 \%$. ESI-MS (MeOH-buffer): Found $m / z=610(\mathrm{M}+\mathrm{H})$ (calculated $\mathrm{m} / \mathrm{z}=$ 609 for $\left.\mathrm{M}^{+}\right)$. Selected IR bands $\left(v_{\max } / \mathrm{cm}^{-1}\right): 1612 \& 1526$ $(\mathrm{C}=\mathrm{N}-\mathrm{N}=\mathrm{C}) ; 1398$ (phenolic, $\mathrm{C}-\mathrm{O}$ ); 1327 (enolic, $\mathrm{C}-\mathrm{O}$ ); $1096(\mathrm{~N}-\mathrm{N}) . \delta_{\mathrm{H}}\left(500 \mathrm{MHz} ; \mathrm{DMSO}-\mathrm{d}_{6} ; \mathrm{Me}_{4} \mathrm{Si}\right): 9.32(1 \mathrm{H}, \mathrm{s}$, $\mathrm{HC}=\mathrm{N}) ; 7.86-6.37(25 \mathrm{H}, \mathrm{m}, \mathrm{Ar}-\mathrm{H})$.

\section{Physical measurements and instrumentation}

Elemental analyses $(\% \mathrm{C}, \mathrm{H} \& \mathrm{~N})$ were performed on a Vario EL III CHNS analyzer and all IR spectra were recorded as $\mathrm{KBr}$ pellets on a Nicolet Avatar instrument in the frequency range $400-4000 \mathrm{~cm}^{-1}$. The electronic absorption and emission spectra were recorded in DMSO-buffer $(5: 95)$ solution on a Jasco V-630 spectrophotometer and Jasco FP 6600 spectrofluorometer respectively at room temperature. ${ }^{1} \mathrm{H}$ NMR spectra of the ligands and corresponding nickel(II) complexes were recorded on a Bruker AMX $500 \mathrm{MHz}$ spectrometer using tetramethylsilane as an internal standard and DMSO as a solvent. The electrospray mass spectra of the complexes and ligands (ESI-MS) in methanol-buffer $(5: 95)$ was recorded on a THERMO Finnigan LCQ Advantage max ion trap mass spectrometer. The X-ray diffraction data of complexes $\mathbf{4}$ and $\mathbf{5}$ were collected at $100 \mathrm{~K}$ respectively with $\mathrm{MoK} \alpha$ radiation $(\lambda=0.71073$ and $0.71069 \AA)$ using a Bruker Smart APEX II CCD diffractometer equipped with graphite monochromator. The structures were solved by direct methods and refined full-matrix least squares (on $F^{2}$ ) SHELXS97 and SHELXL97 ${ }^{31}$ and the graphics were produced using PLATON97. ${ }^{32}$ All the non-hydrogen atoms were refined anisotropically and the hydrogen atoms were positioned geometrically and refined as riding model.

\section{DNA binding studies}

Electronic absorption spectroscopy. All the experiments involving the interaction of the hydrazone ligands $\mathbf{1}-\mathbf{3}$ and their nickel complexes 4-6 with DNA were carried out using $10 \mathrm{mM}$ Tris buffer at $\mathrm{pH}$ 7.2. Solutions of calf thymus DNA in the buffer showed UV-visible absorption bands at 260 and $280 \mathrm{~nm}$ with a ratio of $1.9: 1$, indicating the protein free nature of DNA. ${ }^{33}$ The DNA concentration per nucleotide was determined by absorption spectroscopy using the molar absorption coefficient $\left(6600 \mathrm{M}^{-1} \mathrm{~cm}^{-1}\right)$ at $260 \mathrm{~nm} \cdot{ }^{34}$ Electronic absorption titration experiments were performed by maintaining the concentration of test compounds as constant $(25 \mu \mathrm{M})$ but with variable nucleotide concentration from 0 to $25 \mu \mathrm{M}$. While measuring the absorption spectra, equal amounts of DNA were added to both test compounds and reference solutions to eliminate the absorbance of DNA itself. The data were then fit into the following equation and the intrinsic binding constant $K_{\mathrm{b}}$ was calculated in each case. ${ }^{35}$

$$
[\mathrm{DNA}] /\left[\varepsilon_{\mathrm{a}}-\varepsilon_{\mathrm{f}}\right]=[\mathrm{DNA}] /\left[\varepsilon_{\mathrm{b}}-\varepsilon_{\mathrm{f}}\right]+1 / K_{\mathrm{b}}\left[\varepsilon_{\mathrm{b}}-\varepsilon_{\mathrm{f}}\right]
$$

where, [DNA] is the concentration of DNA in base pairs, $\varepsilon_{\mathrm{a}}$ is the extinction coefficient of the ligand/complex at a given DNA concentration, $\varepsilon_{\mathrm{f}}$ is the extinction coefficient of the complex in free solution and $\varepsilon_{\mathrm{b}}$ is the extinction coefficient of the ligand/ complex when fully bound to DNA. A plot of [DNA] versus $[\mathrm{DNA}] /\left[\varepsilon_{\mathrm{b}}-\varepsilon_{\mathrm{f}}\right]$ gave a slope and an intercept equal to $1 /\left[\varepsilon_{\mathrm{a}}-\varepsilon_{\mathrm{f}}\right]$ and $\left(1 / K_{\mathrm{b}}\right)\left[\varepsilon_{\mathrm{b}}-\varepsilon_{\mathrm{f}}\right]$, respectively. The intrinsic binding constant $K_{\mathrm{b}}$ is the ratio of the slope to the intercept.

\section{Competitive binding fluorescence measurements}

The apparent binding constant $\left(K_{\text {app }}\right)$ of the ligands $\mathbf{1}-\mathbf{3}$ and their complexes 4-6 with DNA was determined by a fluorescence spectral technique using ethidiumbromide (EB) bound CT DNA solution in Tris- $\mathrm{HCl}$ buffer solution $(\mathrm{pH}, 7.2)$. The changes in fluorescence intensities at $604 \mathrm{~nm}$ (515 nm excitation) of EB bound to DNA were measured with respect to different concentration of the compounds $(0-150 \mu \mathrm{M})$. EB was non-emissive in 
Tris- $\mathrm{HCl}$ buffer solution $(\mathrm{pH}, 7.2)$ due to fluorescence quenching of free $\mathrm{EB}$ by the solvent molecules. In the presence of DNA, EB showed enhanced emission intensity due to its intercalative binding to DNA. A competitive binding of the ligand/ metal complexes to CT DNA resulted in the displacement of the bound EB thereby decreasing its emission intensity. The quenching constant $\left(K_{\mathrm{q}}\right)$ was calculated using the classical SternVolmer equation. $^{36}$

$$
I_{0} / I=K_{\mathrm{q}}[\mathrm{Q}]+1
$$

$I_{0}$ is the emission intensity in the absence of quencher, $I$ is the emission intensity in the presence of quencher, $K_{\mathrm{q}}$ is the quenching constant, [Q] is the quencher (complexes) concentration and $K_{\mathrm{q}}$ is the slope, obtained from the plot of $I_{0} / I v s$. [Q]. The apparent binding constant $\left(K_{\text {app }}\right)$ has been calculated from the equation,

$$
K_{\mathrm{EB}}[\mathrm{EB}]=K_{\mathrm{app}}[\text { complex }]
$$

The ligand/complex concentration was obtained from the value at a $50 \%$ reduction of the fluorescence intensity of $\mathrm{EB}$, $K_{\mathrm{EB}}=1.0 \times 10^{7} \mathrm{M}^{-1}$ and $[\mathrm{EB}]=5 \mu \mathrm{M}$.

\section{Protein binding studies}

Binding of ligands 1-3 and its corresponding nickel hydrazone complexes 4-6 with bovine serum albumin (BSA) was studied using fluorescence spectra recorded with an excitation at $280 \mathrm{~nm}$ and corresponding emission at $345 \mathrm{~nm}$ assignable to that of free bovine serum albumin (BSA). The excitation and emission slit widths and scan rates were constantly maintained for all the experiments. Samples were carefully degassed using pure nitrogen gas for 15 minutes by using quartz cells $(4 \times 1 \times 1 \mathrm{~cm})$ with high vacuum Teflon stopcocks. Stock solution of BSA was prepared in $50 \mathrm{mM}$ phosphate buffer $(\mathrm{pH}, 7.2)$ and stored in dark at $4{ }^{\circ} \mathrm{C}$ for further use. Concentrated stock solutions of test compounds were prepared by dissolving them in DMSO-phosphate buffer $(5: 95)$ and diluted suitably with phosphate buffer to get required concentrations. $2.5 \mathrm{ml}$ of BSA solution $(1 \mu \mathrm{M})$ was titrated by successive additions of a $10^{-4} \mathrm{M}$ stock solution of ligands/complexes using a micropipette. Synchronous fluorescence spectra were also recorded using the same concentration of BSA and complexes as mentioned above with two different $\Delta \lambda$ (difference between the excitation and emission wavelengths of BSA) values such as 15 and $60 \mathrm{~nm}$.

\section{Antioxidant studies}

The superoxide, hydroxyl and nitric radical scavenging activities of all the three ligands and their corresponding complexes were determined by the methods described by Beauchamp et al., Nash and Green et al., respectively. ${ }^{37-39}$ For each of the above assays, tests were run in triplicate by varying the concentration of compounds ranging from $10-50 \mu \mathrm{M}$.

The percentage activity was calculated by using the formula,

$$
\% \text { activity }=\left[\left(A_{0}-A_{\mathrm{C}}\right) / A_{0}\right] \times 100
$$

where, $A_{0}$ and $A_{\mathrm{C}}$ represent the absorbance in the absence and presence of the test compounds, respectively. The 50\% activity $\left(\mathrm{IC}_{50}\right)$ can be calculated from the result of percentage activity.

\section{Cytotoxicity}

In vitro cytotoxicity $\left(\mathrm{IC}_{50}\right)$ of the synthesised compounds was performed on HeLa (human cervical cancer cells), A431 (human skin cancer cells), HepG2 (human liver hepatocellular carcinoma cells) and normal NIH 3 T3 (mouse embryonic cells) cell lines using MTT assay method. ${ }^{40}$ Tumour cell lines (HeLa, A431 and HepG2) used in this work were grown in Eagles Minimum Essential Medium containing 10\% fetal bovine serum (FBS) and NIH 3 T3 fibroblasts were grown in Dulbeccos Modified Eagles Medium (DMEM) containing 10\% FBS. For screening studies, the cells were seeded into 96 -well plates in $100 \mu \mathrm{l}$ of respective medium containing 10\% FBS, at a plating density of 10000 cells per well and incubated at $37{ }^{\circ} \mathrm{C}, 5 \% \mathrm{CO}_{2}, 95 \%$ air and $100 \%$ relative humidity for $24 \mathrm{~h}$ prior to addition of test compounds. The test compounds were dissolved in dimethylsulfoxide and diluted in respective serum free medium. After $24 \mathrm{~h}, 100 \mu \mathrm{l}$ of the medium containing the test compounds at various concentrations (in the range of 15 to $500 \mu \mathrm{M}$ for all the ligands and precursor complex to HeLa, HepG-2 and NIH 3T3 normal cell lines whereas $6.25-200 \mu \mathrm{M}$ of complex 4 and $3.12-100 \mu \mathrm{M}$ concentration of complexes $\mathbf{5}$ and $\mathbf{6}$ to the A431 cell lines) was added and incubated at $37{ }^{\circ} \mathrm{C}, 5 \% \mathrm{CO}_{2}, 95 \%$ air and $100 \%$ relative humidity for $48 \mathrm{~h}$. Triplicate was maintained and the medium containing no test compounds served as control.

After $48 \mathrm{~h}, 15 \mu \mathrm{l}$ of MTT ( $5 \mathrm{mg} \mathrm{ml}^{-1}$ ) in phosphate buffered saline (PBS) was added to each well and incubated at $37{ }^{\circ} \mathrm{C}$ for $4 \mathrm{~h}$. The medium with MTT was then flicked off and the formed formazan crystals were solubilized in $100 \mu \mathrm{l}$ of DMSO and the absorbance at $570 \mathrm{~nm}$ was measured using micro plate reader. The $\%$ cell inhibition was determined using the following formula, $\%$ cell inhibition $=100-\mathrm{Abs}_{(\text {drug })} / \mathrm{Abs}_{(\text {control })} \times 100$ and a graph was plotted between $\%$ cell inhibition and concentration of the drug (complexes). From the graph, $\mathrm{IC}_{50}$ values were also calculated.

\section{Results and discussion}

The reactions of $\left[\mathrm{NiCl}_{2}\left(\mathrm{PPh}_{3}\right)_{2}\right]$ with the respective hydrazone ligands, furan-2-carboxylic acid (3-hydroxy-naphthalen-2ylmethylene)-hydrazide $\left(\mathrm{H}_{2} \mathrm{~L}^{1}\right)$ (1) (or) thiophene-2-carboxylic acid (3-hydroxy-naphthalen-2ylmethylene)-hydrazide $\left(\mathrm{H}_{2} \mathrm{~L}^{2}\right)(2)$ (or) isonicotinic acid (3-hydroxy-naphthalen-2-ylmethylene)hydrazide $\left(\mathrm{H}_{2} \mathrm{~L}^{3}\right)(3)$ yielded complexes of the type $\left[\mathrm{Ni}\left(\mathrm{L}^{1-3}\right)\right.$ $\left(\mathrm{PPh}_{3}\right)$ ] (4-6) (Scheme 1). The analytical data of the above said complexes were in good agreement with the proposed molecular formulae of 1:1 metal to ligand stoichiometries (given under the experimental part). All the synthesised compounds are quite stable in air and light and soluble in most of the organic solvents such as $\mathrm{MeOH}, \mathrm{EtOH}, \mathrm{CH}_{2} \mathrm{Cl}_{2}, \mathrm{CHCl}_{3}, \mathrm{DMF}$ and DMSO and were well characterised using several physico-chemical techniques. 


\section{Infrared spectroscopy}

The IR spectra of the metal hydrazone complexes were compared with those of respective free hydrazone ligands in the region $4000-400 \mathrm{~cm}^{-1}$. The spectra of the ligands $\mathbf{1}-\mathbf{3}$ displayed characteristic absorption bands in the range of 3405-3442, 3212-3225, 1639-1640, 1586-1606, 1240-1282 and $1016-1037 \mathrm{~cm}^{-1}$ due to $v_{(\mathrm{O}-\mathrm{H})}, v_{(\mathrm{N}-\mathrm{H})}, v_{(\mathrm{C}=\mathrm{O})}, v_{(\mathrm{C}=\mathrm{N})} v_{(\mathrm{C}-\mathrm{OH})}$ and $v_{(\mathrm{N}-\mathrm{N})}$ vibrations, respectively. The bands due to $v_{(\mathrm{N}-\mathrm{H})}$ and $v_{(\mathrm{C}=\mathrm{O})}$ vibrations of the free ligands were absent for complexes 4-6, thus indicating that enolisation and deprotonation had taken place prior to coordination. This fact was further confirmed by the appearance of two new bands in the spectra of complexes around $1614-1519 \mathrm{~cm}^{-1}$ and $1360-1398 \mathrm{~cm}^{-1}$ that corresponds to $v_{(\mathrm{C}=\mathrm{N}-\mathrm{N}=\mathrm{C})}$ and $v_{(\mathrm{C}-\mathrm{O})}$ stretching vibrations, respectively. The bands attributed to $v_{(\mathrm{C}=\mathrm{N})}$ stretching were shifted to higher frequencies while a positive shift of about $\approx 18-80 \mathrm{~cm}^{-1}$ was observed for the $v_{(\mathrm{N}-\mathrm{N})}$ stretching vibration in comparison with that of their respective free ligands, thus implying that the nitrogen atom of the azomethine group is coordinated to the metal in these complexes. All these facts suggested that the hydrazone ligands behave as a monobasic bidentate (NO) chelating ligands in all the three complexes 4-6.

\section{${ }^{1}$ H NMR spectroscopy}

${ }^{1} \mathrm{H}$ NMR spectra of the free hydrazone ligands and their complexes were assigned on the basis of observed chemical shifts. The spectra of the ligands 1-3 displayed a weak singlet respectively at $9.43,9.28$ and $9.51 \mathrm{ppm}$ due to the $\mathrm{NH}$ proton. The other characteristic resonance due to an $\mathrm{OH}$ proton (formed via keto-enol tautomerization of the hydrazone ligand) appears in the range of 13.18-12.24 ppm. But, the NMR spectra of complexes 4-6 did not register any signal corresponding to $\mathrm{NH}$, revealing that the ligands adopted an enol form, followed by deprotonation prior to coordination with the metal ion. In addition, all the ligands showed a sharp singlet for azomethine $(\mathrm{HC}=\mathrm{N})$ proton respectively at $8.05,8.34$ and $8.23 \mathrm{ppm}$. However, in the case of spectra of nickel hydrazone complexes, the signal corresponding to the azomethine protons gets shifted downfield due to the participation of azomethine nitrogen in coordination with metal ion and observed at 8.16, 9.23 and $9.32 \mathrm{ppm}$, respectively. The signals corresponding to the protons of aromatic moieties of the ligands and their complexes were observed as multiplets in the range of 6.37-8.01 ppm.

\section{Description of solid state structures}

The solid-state structure of complexes $\mathbf{4}$ and $\mathbf{5}$ were analysed with single crystal X-ray diffraction study. Details of the data collection conditions and the parameters of refinement process are given in Table 1. The perspective ORTEP views of the complexes $\mathbf{4}$ and $\mathbf{5}$ with atom numbering scheme are depicted in Fig. 1 and 2 with corresponding selected geometric parameters given in Table 2.

Dark-red, tetragonal shaped crystals of both complexes $\mathbf{4}$ and 5 belong to the monoclinic crystal system with $P 21 / c$ space group. In both the complexes $\left[\mathrm{Ni}\left(\mathrm{L}^{1}\right)\left(\mathrm{PPh}_{3}\right)\right]$ and $\left[\mathrm{Ni}\left(\mathrm{L}^{2}\right)\right.$ $\left.\left(\mathrm{PPh}_{3}\right)\right]$, the coordination geometry around the nickel ion is
Table 1 Crystal structure data of complexes $\mathbf{4}$ and $\mathbf{5}$

\begin{tabular}{|c|c|c|}
\hline & Complex 4 & Complex 5 \\
\hline Formula & $\mathrm{C}_{34} \mathrm{H}_{25} \mathrm{~N}_{2} \mathrm{NiO}_{3} \mathrm{P}$ & $\mathrm{C}_{34} \mathrm{H}_{25} \mathrm{~N}_{2} \mathrm{NiO}_{2} \mathrm{PS}$ \\
\hline Formula weight & 599.24 & 615.30 \\
\hline Temperature (K) & $100(2)$ & $100(2)$ \\
\hline$\lambda(\AA)$ & 0.71073 & 0.71069 \\
\hline Crystal system & Monoclinic & Monoclinic \\
\hline Space group & $P 21 / c$ & $P 21 / c$ \\
\hline \multicolumn{3}{|l|}{ Cell dimensions } \\
\hline$a(\AA)$ & $10.379(2)$ & $15.499(3)$ \\
\hline$b(\AA)$ & $14.886(3)$ & $10.844(5)$ \\
\hline$c(\AA)$ & $19.785(6)$ & $21.084(4)$ \\
\hline$\alpha\left(^{\circ}\right)$ & 90 & 90 \\
\hline$\beta\left(^{\circ}\right)$ & $116.60(2)$ & $125.601(15)$ \\
\hline$\gamma\left({ }^{\circ}\right)$ & 90 & 90 \\
\hline$Z$ & 4 & 4 \\
\hline \multirow{3}{*}{$h k l$ limits } & $-13 \leq h \geq 13$ & $-20 \leq h \geq 20$ \\
\hline & $-19 \leq k \geq 15$ & $-14 \leq k \geq 12$ \\
\hline & $-25 \leq l \geq 25$ & $-27 \leq l \geq 27$ \\
\hline$D_{\text {calcd }}\left(\mathrm{Mg} \mathrm{m}^{-3}\right)$ & 1.456 & 1.418 \\
\hline$F(000)$ & 1240 & 1272 \\
\hline Crystal size $\left(\mathrm{mm}^{3}\right)$ & $0.11 \times 0.06 \times 0.05$ & $0.28 \times 0.15 \times 0.14$ \\
\hline Independent reflections & $6193[R($ int $)=0.0666]$ & $6598[R(\mathrm{int})=0.0294]$ \\
\hline $\begin{array}{l}\text { Data/ } \\
\text { restraints/parameters }\end{array}$ & $6193 / 0 / 370$ & $6598 / 0 / 370$ \\
\hline Goodness-of-fit on $F^{2}$ & 1.503 & 1.081 \\
\hline Final $R$ indices & $R_{1}=0.0880$ & $R_{1}=0.0284$ \\
\hline$[I>2 \sigma(I)]$ & $\mathrm{w} R_{2}=0.1057$ & $\mathrm{w} R_{2}=0.0723$ \\
\hline$R$ indices (all data) & $\begin{array}{l}R_{1}=0.1854, \\
\mathrm{w} R_{2}=0.1279\end{array}$ & $\begin{array}{l}R_{1}=0.0322, \\
\mathrm{w} R_{2}=0.0738\end{array}$ \\
\hline
\end{tabular}

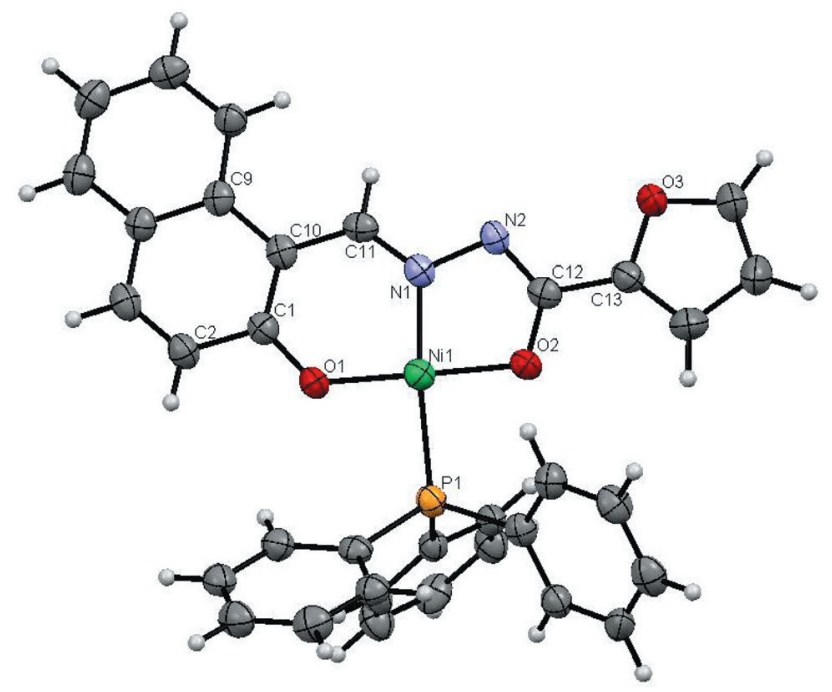

Fig. 1 The molecular structure of complex 4, with displacement ellipsoids drawn at the $50 \%$ probability level.

distorted square planar in which the dianionic ligand acted as a planar tridentate forming a five-membered and a six-membered metallocycle involving the metal ion. As expected, the hydrazone ligand is bonded to the nickel ion via both phenolate and enolate oxygen atoms and the imine nitrogen atom, the corresponding bite angles being $94.5(1)^{\circ}, 84.3(1)^{\circ}$ and $94.54(6)^{\circ}$, $84.16(6)^{\circ}$ for [O1-Ni1-N1] and [N1-Ni1-O2] respectively for complexes $\mathbf{4}$ and $\mathbf{5}$. The ONO donor set of atoms of the ligand 


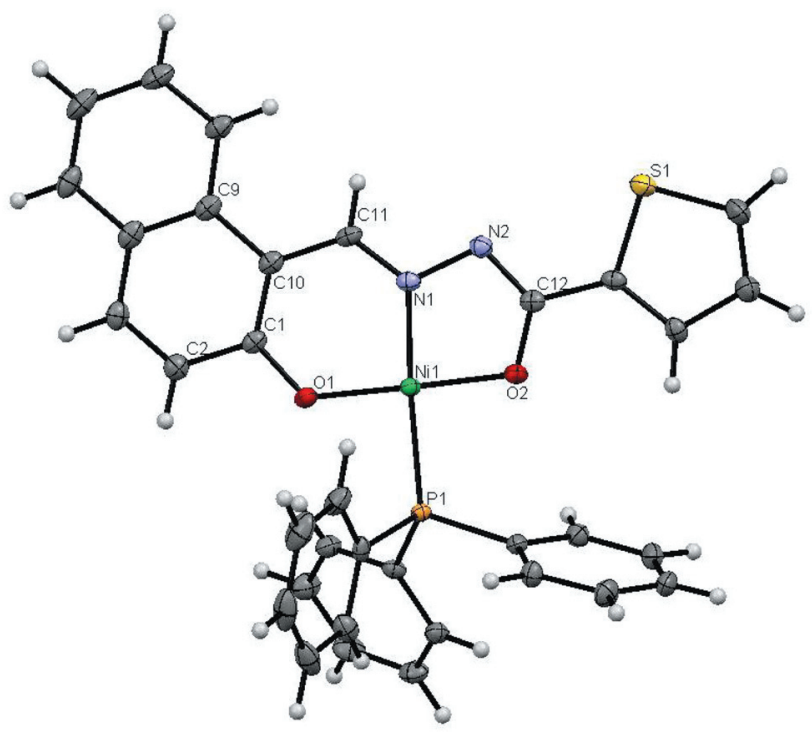

Fig. 2 The molecular structure of complex 5, with displacement ellipsoids drawn at the $50 \%$ probability level.

occupies three of the four coordination sites of the square planar arrangement with the remaining one occupied by the phosphorus atom of the triphenylphosphine. The unequal bond lengths and bond angles corresponding to complexes $\mathbf{4}$ and $\mathbf{5}$ (given in Table 2) indicated a distortion from the regular square planar geometry. The unit cell packing diagram of complexes $\mathbf{4}$ and $\mathbf{5}$ is presented in Fig. S1 and S2. $\dagger$

\section{DNA binding studies}

UV-visible absorption studies. The electronic absorption spectra of hydrazone ligands $\mathbf{1 - 3}$ and respective nickel hydrazone chelates 4-6 in DMSO-buffer displayed five or six well-resolved bands in the range of 200 to $470 \mathrm{~nm}$. The absorption bands in the range of $270-460 \mathrm{~nm}$ for ligands 1-3 have been assigned to charge transfer transitions of the type $\pi \rightarrow \pi^{*}$ and $n \rightarrow \pi^{*}$. In the case of complexes 4-6, the high energy absorption bands appeared between 250-300 $\mathrm{nm}$ and another absorption around $320-360 \mathrm{~nm}$ were assigned to the intra-ligand charge transfer transitions of the type $\pi \rightarrow \pi^{*}$ and $n \rightarrow \pi^{*}{ }^{41}$

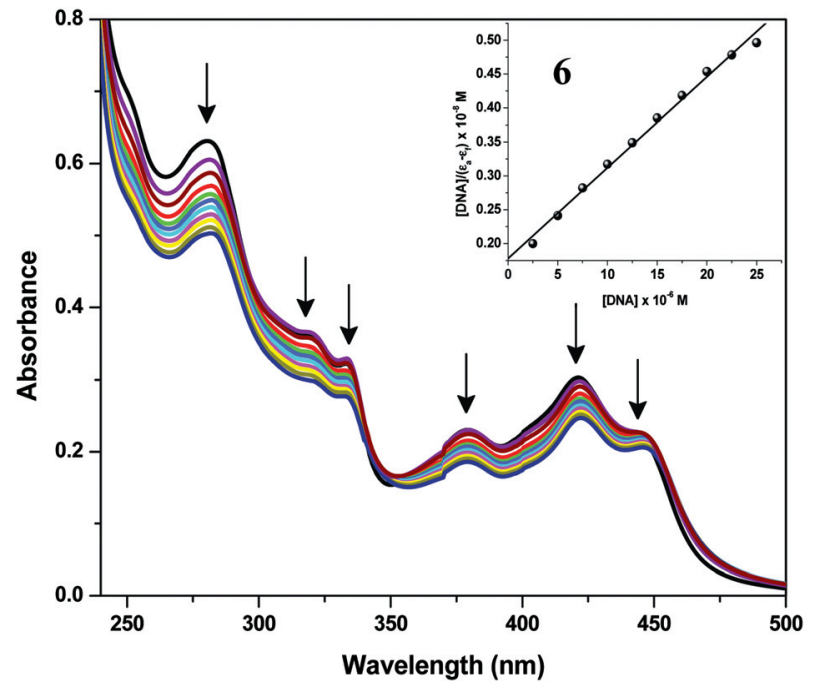

Fig. 3 Electronic absorption spectra of complex $6(25 \mu \mathrm{M})$ in the absence and presence of increasing amounts of CT DNA $(2.5,5.0,7.5$, $10.0,12.5,15.0,17.5$ and $20.0,22.5$ and $25 \mu \mathrm{M}$ ). Arrows show the changes in absorbance as a function of increasing DNA concentration (inset: plot of [DNA] $v s$. [DNA] $/\left(\varepsilon_{\mathrm{a}}-\varepsilon_{\mathrm{f}}\right)$ ).

Further, the bands appeared around 370 and $450 \mathrm{~nm}$ for complexes have been assigned to ligand-to-metal charge transfer (LMCT) as well as metal-to-ligand charge transfer (MLCT) transitions, respectively. ${ }^{42,43}$ The electronic absorption spectra of compounds (ligands/complexes) 1-6 without as well as with the added CT DNA is shown in Fig. S3, S4 $\uparrow$ and 3.

From the electronic absorption spectral data, it is clear that upon increasing concentration of DNA added to the ligands 1-3 showed only hypochromism without any shift in wavelength whereas in metal complexes 4-6, all the above mentioned absorption bands showed hypochromism accompanied with small red or blue shifts in most of the absorption bands. The nature of the shifts observed and the percentage of hypochromism in the absorption bands in the case of all the compounds after the addition of DNA given in Table 3 suggested that the nickel hydrazone complexes bound more strongly to DNA than their respective ligands via an intercalative mode. These observations were similar to those reported earlier for various metallointercalators. $^{44}$

Table 2 Selected bond lengths $(\AA)$ and bond angles $\left({ }^{\circ}\right)$

\begin{tabular}{|c|c|c|c|c|c|c|c|}
\hline \multicolumn{4}{|c|}{$\mathrm{C}_{34} \mathrm{H}_{25} \mathrm{~N}_{2} \mathrm{Ni} \mathrm{O}_{3} \mathrm{P}(4)$} & \multicolumn{4}{|c|}{$\mathrm{C}_{34} \mathrm{H}_{25} \mathrm{~N}_{2} \mathrm{Ni} \mathrm{O}_{2}$ P S (5) } \\
\hline Ni1-O1 & $1.814(3)$ & $\mathrm{P} 1-\mathrm{Ni1}-\mathrm{O} 1$ & $90.91(1)$ & Ni1-O1 & $1.824(2)$ & $\mathrm{O} 1-\mathrm{Ni1}-\mathrm{P} 1$ & $89.39(4)$ \\
\hline $\mathrm{Ni} 1-\mathrm{O} 2$ & $1.842(3)$ & P1-Ni1-O2 & $90.2(1)$ & $\mathrm{Ni1}-\mathrm{O} 2$ & $1.848(2)$ & $\mathrm{O} 2-\mathrm{Ni1}-\mathrm{P} 1$ & $91.97(4)$ \\
\hline Ni1-P1 & $2.224(1)$ & $\mathrm{O} 2-\mathrm{Ni1}-\mathrm{N} 1$ & $84.3(1)$ & Ni1-P1 & $2.216(7)$ & $\mathrm{N} 1-\mathrm{Ni1}-\mathrm{O} 2$ & $84.16(6)$ \\
\hline C9-C10 & $1.454(7)$ & P1-Ni1-N1 & 173.1(1) & C9-C10 & $1.455(3)$ & N1-Ni1-P1 & $175.39(4)$ \\
\hline $\mathrm{N} 1-\mathrm{N} 2$ & $1.413(4)$ & N2-N1-C11-C10 & $-179.7(4)$ & $\mathrm{N} 1-\mathrm{N} 2$ & $1.401(2)$ & $\mathrm{C} 10-\mathrm{C} 11-\mathrm{N} 1-\mathrm{N} 2$ & $178.4(1)$ \\
\hline $\mathrm{N} 2-\mathrm{C} 12$ & $1.307(6)$ & $\mathrm{C} 11-\mathrm{N} 1-\mathrm{N} 2-\mathrm{C} 12$ & $-175.8(4)$ & $\mathrm{C} 12-\mathrm{N} 2$ & $1.308(3)$ & $\mathrm{C} 11-\mathrm{N} 1-\mathrm{N} 2-\mathrm{C} 12$ & $176.6(1)$ \\
\hline $\mathrm{C} 12-\mathrm{C} 13$ & $1.456(5)$ & $\mathrm{N} 1-\mathrm{N} 2-\mathrm{C} 12-\mathrm{C} 13$ & $-176.1(4)$ & $\mathrm{C} 12-\mathrm{C} 13$ & $1.463(3)$ & $\mathrm{C} 13-\mathrm{C} 12-\mathrm{N} 2-\mathrm{N} 1$ & $-179.3(1$ \\
\hline
\end{tabular}


Table 3 Nature of shift with \% of hypochromism

\begin{tabular}{|c|c|c|c|c|}
\hline Complex & $\begin{array}{l}\text { Absorption } \\
\text { wavelength } \\
(\mathrm{nm})\left(\varepsilon_{\max } \text { in }\right. \\
\left.\mathrm{cm}^{-1} \mathrm{~mol}^{-1}\right) \\
\text { (absence of } \\
\text { DNA) }\end{array}$ & $\begin{array}{l}\text { Shift of } \\
\text { wavelength } \\
(\mathrm{nm}) \\
\text { (presence of } \\
\text { DNA) }\end{array}$ & $\begin{array}{l}\text { Nature } \\
\text { of shift }\end{array}$ & $\begin{array}{l}\% \text { of } \\
\text { hypochromism }\end{array}$ \\
\hline \multirow[t]{5}{*}{1} & $286(9492)$ & - & - & 10.74 \\
\hline & 323 (9932) & - & - & 9.62 \\
\hline & $334(10216)$ & - & - & 11.92 \\
\hline & 378 (12 112) & - & - & 11.82 \\
\hline & $398(11400)$ & - & - & 11.65 \\
\hline \multirow[t]{6}{*}{2} & $270(4820)$ & - & - & 10.74 \\
\hline & $319(3452)$ & - & - & 13.89 \\
\hline & 333 (4096) & - & - & 9.07 \\
\hline & 360 (4004) & - & - & 12.86 \\
\hline & $376(4104)$ & - & - & 4.24 \\
\hline & $401(3340)$ & - & - & 14.97 \\
\hline \multirow[t]{6}{*}{3} & $313(11608)$ & - & - & 11.65 \\
\hline & $327(16568)$ & - & - & 12.29 \\
\hline & $346(13768)$ & - & - & 11.20 \\
\hline & 367 (14 384) & - & - & 10.09 \\
\hline & 439 (9008) & - & - & 11.09 \\
\hline & $460(7956)$ & - & - & 11.77 \\
\hline \multirow{5}{*}{4} & $282(19368)$ & 3 & Blue & 16.81 \\
\hline & $312(14256)$ & - & - & 18.15 \\
\hline & $379(7980)$ & 1 & Red & 16.99 \\
\hline & $424(10652)$ & - & - & 16.64 \\
\hline & 450 (9144) & - & - & 13.99 \\
\hline \multirow[t]{6}{*}{5} & $283(23868)$ & - & - & 18.13 \\
\hline & $319(15688)$ & 2 & Blue & 19.02 \\
\hline & $333(14448)$ & 1 & Blue & 17.60 \\
\hline & $380(9800)$ & - & - & 20.08 \\
\hline & $422(12528)$ & 1 & Red & 17.72 \\
\hline & 445 (9536) & 2 & Red & 6.96 \\
\hline \multirow[t]{6}{*}{6} & $281(25268)$ & 1 & Red & 20.34 \\
\hline & $319(14516)$ & 1 & Blue & 17.19 \\
\hline & $333(12900)$ & 2 & Blue & 14.14 \\
\hline & $379(9212)$ & - & - & 19.32 \\
\hline & $421(121200)$ & 2 & Red & 18.48 \\
\hline & $446(86680)$ & - & - & 4.93 \\
\hline
\end{tabular}

In order to determine quantitatively the binding strength of the ligands and its complexes with CT DNA, intrinsic binding constants were obtained by monitoring the changes in both the wavelength as well as their corresponding intensity of absorption of the high energy bands upon increasing concentration of added DNA. The following equation was applied to calculate the binding constant: $[\mathrm{DNA}] /\left[\varepsilon_{\mathrm{a}}-\varepsilon_{\mathrm{f}}\right]=[\mathrm{DNA}] /\left[\varepsilon_{\mathrm{b}}-\varepsilon_{\mathrm{f}}\right]+$ $1 / K_{\mathrm{b}}\left[\varepsilon_{\mathrm{b}}-\varepsilon_{\mathrm{f}}\right]$ and the value of the intrinsic binding constant $\left(K_{\mathrm{b}}\right)$ corresponding to the respective ligands 1, 2 and $\mathbf{3}$ and their nickel complexes 4, 5 and $\mathbf{6}$ was found to be $4.60 \pm 0.16 \times 10^{2}$ $\mathrm{M}^{-1}, 5.14 \pm 0.20 \times 10^{2} \mathrm{M}^{-1}, 6.64 \pm 0.15 \times 10^{3} \mathrm{M}^{-1}, 3.00 \pm$ $0.12 \times 10^{4} \mathrm{M}^{-1}, 4.60 \pm 0.19 \times 10^{4} \mathrm{M}^{-1}$ and $7.52 \pm 0.22 \times 10^{4}$ $\mathrm{M}^{-1}$. The magnitude of the binding constant value clearly showed that complex 6 bound more strongly with CT DNA than the rest of the complexes through an intercalative mode whereas the free hydrazone ligands displayed a electrostatic binding mode of interactions.

\section{Competitive binding between EB and ligands/complexes for CT DNA}

Fluorescence quenching of the EB-DNA complex is used to monitor the binding of test compounds to DNA regardless of

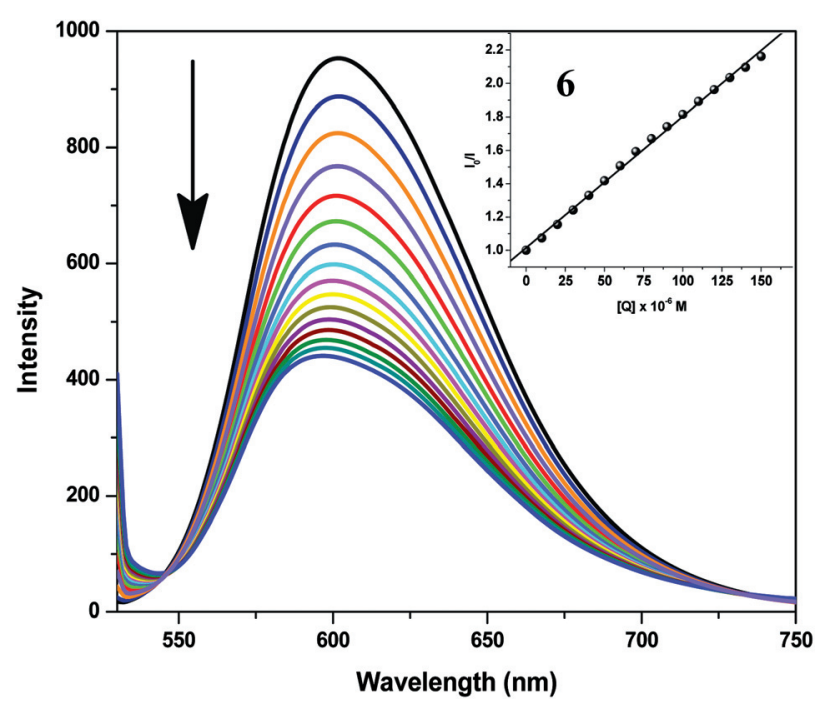

Fig. 4 Emission spectra of DNA-EB, in the presence of 0, 10, 20, 30, $40,50,60,70,80,90,100,110,120,130,140$ and $150 \mu \mathrm{M}$ of complex 6. Arrow indicates the change in the emission intensity as a function of complex concentration (inset: Stern-Volmer plot of the fluorescence titration data corresponding to the complex).

their binding modes and only measures their ability to influence the EB luminescence intensities in the EB-DNA complex. ${ }^{45}$ It has been previously reported that the fluorescence intensity of EB-DNA could be decreased by addition of the ligands/complexes as quenchers, indicating the competition between the ligands/complexes and EB in binding to DNA that proved the intercalation of ligands/metal complexes to the base pairs of DNA. ${ }^{46,47}$

The fluorescence emission spectra of EB bound to DNA in the absence and presence of the three complexes are shown in Fig. S5, S6† and 4. From the figures, it is clear that an appreciable reduction in the fluorescence intensity at $604 \mathrm{~nm}$ of about $12.64,16.40,17.99,41.55,50.43$ and $53.74 \%$ together with blue shifts of $0,0,0,2,5$ and $5 \mathrm{~nm}$, respectively, was observed on addition of free ligands $\mathbf{1 - 3}$ and their $\mathrm{Ni}$ (II) hydrazone complexes 4-6, respectively to DNA pre-treated with EB, indicating the replacement of EB molecules accompanied by intercalation of the ligands/complexes with DNA. From the plot of intensity against the quencher concentration furnished in Fig. 4, S5 and $\mathrm{S} 6 \dagger$ (as insets), the values of the apparent DNA binding constant $\left(K_{\text {app }}\right)$ were calculated using the equation. ${ }^{48}$

$$
K_{\mathrm{EB}}[\mathrm{EB}]=K_{\text {app }}[\text { complex }]
$$

The test compound concentrations were obtained from the value at $50 \%$ reduction of the fluorescence intensity of $\mathrm{EB}$ and $K_{\mathrm{EB}}=1.0 \times 10^{7} \mathrm{M}^{-1}$ and $[\mathrm{EB}]=5 \mu \mathrm{M}$. The calculated $K_{\mathrm{app}}$ values for ligands 1-3 and their complexes 4-6 are $4.92 \pm 0.11$ $\times 10^{4} \mathrm{M}^{-1}, 6.55 \pm 0.25 \times 10^{4} \mathrm{M}^{-1}, 7.42 \pm 0.17 \times 10^{4} \mathrm{M}^{-1}, 2.40$ $\pm 0.10 \times 10^{5} \mathrm{M}^{-1}, 3.48 \pm 0.15 \times 10^{5} \mathrm{M}^{-1}$ and $4.00 \pm 0.14 \times$ $10^{5} \mathrm{M}^{-1}$, respectively. The fluorescence quenching spectra of DNA-bound EB by ligands and their complexes illustrated that the quenching of EB bound to DNA by the test compounds are in good agreement with the linear Stern-Volmer equation 
(Fig. S5, S6† and 4 as insets). The ratio of the slope to the intercept obtained by plotting $I_{0} / I$ vs. [Q] yielded the value of quenching constant $\left(K_{\mathrm{q}}\right)$ corresponding to the three ligands $\mathbf{1 , 2}$, and $\mathbf{3}$ and their nickel chelates $\mathbf{4 , 5}$ and $\mathbf{6}$ as $9.77 \pm 0.13 \times$ $10^{2} \mathrm{M}^{-1}, 1.31 \pm 0.24 \times 10^{2} \mathrm{M}^{-1}, 1.48 \pm 0.19 \times 10^{3} \mathrm{M}^{-1}, 4.73 \pm$ $0.12 \times 10^{3} \mathrm{M}^{-1}, 7.04 \pm 0.18 \times 10^{3} \mathrm{M}^{-1}$ and $7.76 \pm 0.15 \times 10^{3} \mathrm{M}^{-1}$, respectively. However, the hydrazone ligands $\mathbf{1 - 3}$ did not exhibit much potential to leach out the EB molecules that were originally bound to DNA.

Also, it was assessed that complex $\mathbf{6}$ showed a higher quenching efficiency than the other complexes $\mathbf{4}$ and $\mathbf{5}$ that reflected the strong binding of complex 6 with DNA to leach out more number of EB molecules originally bound to DNA. The binding affinity of the complexes towards DNA increased in the order $\mathbf{4}$ $<\mathbf{5}<\mathbf{6}$. The results of this study strongly support the nature of binding of DNA with complex is intercalation mode. ${ }^{49}$

\section{Protein binding studies}

Fluorescence quenching of BSA by ligands (1-3) and their metal complexes (4-6). Serum albumins are proteins that are amongst others involved in the transport of metal ions and metal complexes with drugs through the blood stream. Binding to these proteins may lead to loss or enhancement of the biological properties of the original drug, or provide paths for drug transportation. Hence, the binding experiments using the newly synthesised hydrazone ligands $\mathbf{1 - 3}$ and their nickel hydrazone complexes 4-6 with BSA were carried out. A generally known fact is that the fluorescence of a protein is caused by three intrinsic characteristics of the protein, namely tryptophan, tyrosine and phenylalanine residues. Fluorescence quenching refers to any process that decreases the fluorescence intensity of a fluorophores due to a variety of molecular interactions including excited state reactions, molecular rearrangements, energy transfer, ground state complex formation and collision quenching. Qualitative analysis of hydrazone ligands and its bivalent nickel hydrazones bound to BSA has been undertaken by examining the respective fluorescence spectra. The intensity of the fluorescence band of BSA observed at $345 \mathrm{~nm}$ was quenched to an extent of about 36.51, 40.98, 42.76, 66.96, 69.01 and 70.62\% from its initial intensity upon the addition of test compounds (ligands/complexes) 1-6 together with a hypsochromic shift of $0,1,1,5,5$ and $6 \mathrm{~nm}$ due to the formation of a hydrazone-BSA complex/nickel hydrazone-BSA complex. Fig. S7, S8† and 5 showed the effect of the increase in the concentration of test compounds 1-6 on the emission intensity of BSA.

The fluorescence quenching is described by Stern-Volmer relation,

$$
I_{0} / I=1+K_{\mathrm{SV}}[\mathrm{Q}]
$$

where, $I_{0}$ and $I$ are the fluorescence intensities of the fluorophore in the absence and presence of quencher, $K_{\mathrm{SV}}$ is the SternVolmer quenching constant and [Q] is the quencher concentration. The $K_{\mathrm{SV}}$ value obtained as a slope from the plot of [Q] vs. $I_{0} / I$ (as insets of Fig. S7, S8† and 5) in respect of ligands 1-3 and their complexes 4-6 are found to be $4.19 \pm 0.18 \times 10^{5} \mathrm{M}^{-1}$, $4.29 \pm 0.12 \times 10^{5} \mathrm{M}^{-1}, 4.82 \pm 0.21 \times 10^{5} \mathrm{M}^{-1}, 1.62 \pm 0.23 \times$

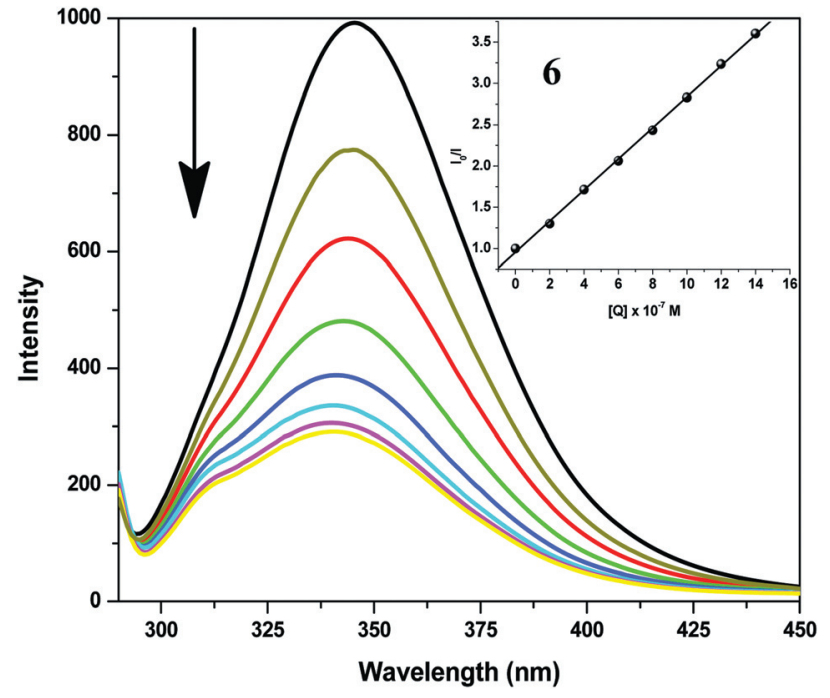

Fig. 5 Emission spectra of BSA $\left(1 \times 10^{-6} \mathrm{M} ; \lambda_{\text {exi }}=280 \mathrm{~nm} ; \lambda_{\text {emi }}=\right.$ $345 \mathrm{~nm})$ as a function of concentration of the complex $6(0,2,4,6,8$, 10,12 and $\left.14 \times 10^{-7} \mathrm{M}\right)$. Arrow indicates the effect of metal complex 6 on the fluorescence emission of BSA (inset: plot of [Q] versus $I_{0} / I$ ).

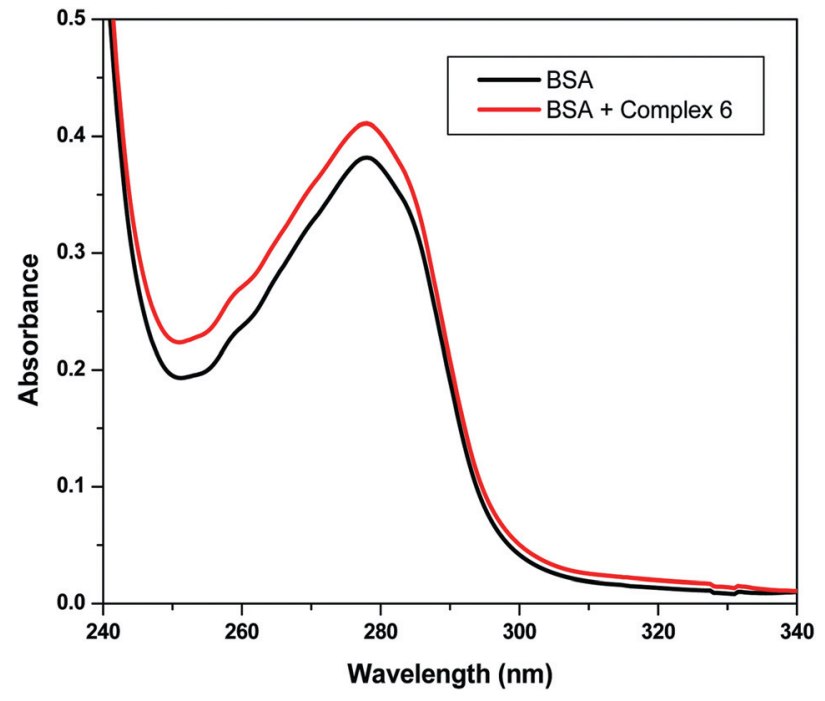

Fig. 6 The absorption spectra of BSA $\left(1 \times 10^{-5} \mathrm{M}\right)$ and BSAcomplex $6\left(\mathrm{BSA}=1 \times 10^{-5} \mathrm{M}\right.$ and complex $\left.6=1 \times 10^{-6} \mathrm{M}\right)$.

$10^{6} \mathrm{M}^{-1}, 1.76 \pm 0.19 \times 10^{6} \mathrm{M}^{-1}$ and $1.88 \pm 0.15 \times 10^{6} \mathrm{M}^{-1}$, respectively.

UV-visible absorption measurement is a simple method to explore the structural changes and is useful to distinguish the type of quenching that exists i.e., static or dynamic quenching. Dynamic quenching only affects the excited states of the fluorophore and there are no changes in the absorption spectra. However, ground-state complex formation will frequently result in perturbation of the absorption spectrum of the fluorophore. From the representative absorption spectra of pure BSA and BSA-complex 6 shown in Fig. 6, it was clear that the addition of complex 6 to a fixed concentration of BSA led to a gradual increase in intensity of BSA absorption but at the same wavelength due to interaction between test compounds and protein. In 
other words, the fluorescence quenching between complex 6 and BSA is mainly ascribed to be static quenching. ${ }^{50}$ Similar observation was also obtained for the rest of the complexes and the free ligands under identical experimental conditions. The above results can be rationalized in terms of the strong interaction between nickel chelates and BSA that caused a change in the conformation of BSA.

\section{Binding constant and number of binding sites}

When small molecules bind independently to a set of equivalent sites on a macromolecule, the equilibrium between free and bound molecules is represented by the Scatchard equation. ${ }^{51}$

$$
\log \left[F_{0}-F / F\right]=\log K+n \log [\mathrm{Q}]
$$

where, $K$ and $n$ are the binding constant and the number of binding sites, respectively.

Thus, a plot of $\log [\mathrm{Q}]$ versus $\log \left(F_{0}-F\right) / F$ (Fig. 7) can be used to determine the values of both $K$ and $n$ and such values calculated for test compounds $\mathbf{1 - 6}$ are listed in Table 4.

From the values of $n$, it is inferred that there is only one independent class of binding sites for complexes on BSA and also a direct relation between the binding constant and number of binding sites.

The results of binding experiments clearly explored that all the three nickel hydrazone chelates showed stronger interactions

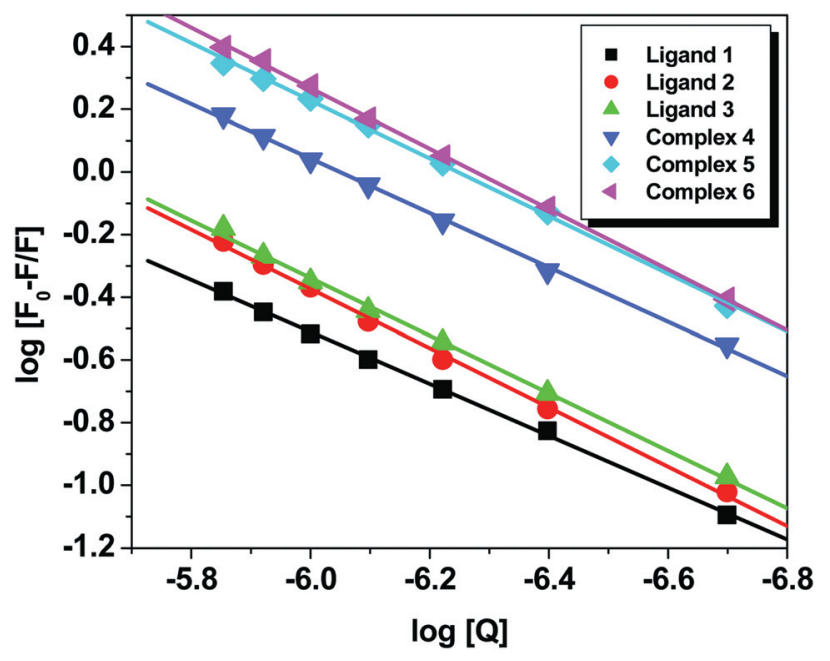

Fig. 7 Plot of $\log [\mathrm{Q}]$ vs. $\log \left[\left(F_{0}-F\right) / F\right]$. with both DNA and BSA than that of the free hydrazone ligands. Generally, these types of binding affinities of metal chelates towards DNA/BSA were due to the strong chelation phenomenon experienced by the hydrazone systems with the bivalent nickel centers. However, among the three types of nickel chelate complexes, the complex $\mathbf{6}$ showed strong binding with both DNA and BSA than the other two complexes. The observed strong binding efficiency of complex $\mathbf{6}$ is attributed to the presence of a six membered pyridine ring at the hydrazide part that has delocalization of electrons in the aromatic ring than the complexes containing five membered systems (complexes 4 and 5). However, among the five membered systems $\mathbf{4}$ and $\mathbf{5}$, the one containing a sulphur atom in its molecular architecture showed a better binding efficiency than the other with oxygen. This fact can be correlated to the electronegativities of oxygen and sulphur atoms in the complexes. The overall order of interaction between the ligands/complexes and CT DNA as well as BSA decreased in the order $\mathbf{6}>\mathbf{5}>\mathbf{4}>\mathbf{3}>\mathbf{2}>\mathbf{1}$. The results of the studies are compared with similar metal complexes reported earlier $^{52,53}$ and are listed in Table 4.

\section{Characteristics of synchronous fluorescence spectra}

Synchronous fluorescence spectroscopy provides information on the molecular microenvironment, particularly in the vicinity of the fluorophore functional groups. ${ }^{54}$ It is well known that the fluorescence of BSA may be due to presence of tyrosine, tryptophan and phenylalanine residues and hence spectroscopic methods are usually applied to study the conformation of serum protein. According to Miller, ${ }^{55}$ in synchronous fluorescence spectroscopy, the difference between excitation and emission wavelength $\left(\Delta \lambda=\lambda_{\text {emi }}-\lambda_{\text {exc }}\right)$ reflects the spectra of a different nature of chromophores, with large $\Delta \lambda$ values such as $60 \mathrm{~nm}$, the synchronous fluorescence of BSA is characteristic of the tryptophan residue and the small $\Delta \lambda$ value such as $15 \mathrm{~nm}$ is characteristic of tyrosine. ${ }^{56}$ To explore the structural changes of BSA due to the addition of free ligands and its nickel(II) hydrazone complexes, we measured synchronous fluorescence spectra of the former with respect to addition of the test compounds 1-6. The synchronous fluorescence spectra of BSA with various concentrations of compounds were recorded at both $\Delta \lambda=15 \mathrm{~nm}$ and $60 \mathrm{~nm}$. Upon increasing the concentration of test compounds, the intensity of emission corresponding to tyrosine (at $302 \mathrm{~nm}$ ) was found to decrease slightly in the magnitude of $16.54,20.38$, $21.29,22.05,23.87$ and $27.11 \%$ for respective ligands $\mathbf{1}, \mathbf{2}, \mathbf{3}$ and complexes 4, 5 and $\mathbf{6}$ without any shift in emission

Table 4 Comparison of interaction study results between compounds 1-6 on DNA and protein

\begin{tabular}{|c|c|c|c|c|c|c|}
\hline \multirow[b]{2}{*}{ Compounds } & \multicolumn{3}{|l|}{ DNA binding } & \multicolumn{3}{|l|}{ Protein binding } \\
\hline & $K_{\mathrm{b}}\left(\mathrm{M}^{-1}\right)$ & $K_{\mathrm{q}}\left(\mathrm{M}^{-1}\right)$ & $K_{\text {app }}\left(\mathrm{M}^{-1}\right)$ & $K_{\mathrm{sv}}\left(\mathrm{M}^{-1}\right)$ & $K\left(\mathrm{M}^{-1}\right)$ & $n$ \\
\hline 1 & $4.60 \pm 0.16 \times 10^{2}$ & $9.77 \pm 0.13 \times 10^{2}$ & $4.92 \pm 0.11 \times 10^{4}$ & $4.19 \pm 0.18 \times 10^{5}$ & $1.50 \pm 0.12 \times 10^{4}$ & 0.6154 \\
\hline 2 & $5.14 \pm 0.20 \times 10^{2}$ & $1.31 \pm 0.24 \times 10^{2}$ & $6.55 \pm 0.25 \times 10^{4}$ & $4.29 \pm 0.12 \times 10^{5}$ & $1.90 \pm 0.08 \times 10^{4}$ & 0.6274 \\
\hline 3 & $6.64 \pm 0.15 \times 10^{3}$ & $1.48 \pm 0.19 \times 10^{3}$ & $7.42 \pm 0.17 \times 10^{4}$ & $4.82 \pm 0.21 \times 10^{5}$ & $2.02 \pm 0.14 \times 10^{4}$ & 0.7042 \\
\hline 4 & $3.00 \pm 0.12 \times 10^{4}$ & $4.73 \pm 0.12 \times 10^{3}$ & $2.40 \pm 0.10 \times 10^{5}$ & $1.62 \pm 0.23 \times 10^{6}$ & $1.80 \pm 0.10 \times 10^{5}$ & 0.8688 \\
\hline 5 & $4.60 \pm 0.19 \times 10^{4}$ & $7.04 \pm 0.18 \times 10^{3}$ & $3.48 \pm 0.15 \times 10^{5}$ & $1.76 \pm 0.19 \times 10^{6}$ & $5.67 \pm 0.15 \times 10^{5}$ & 0.9210 \\
\hline 6 & $7.52 \pm 0.22 \times 10^{4}$ & $7.76 \pm 0.15 \times 10^{3}$ & $4.00 \pm 0.14 \times 10^{5}$ & $1.88 \pm 0.15 \times 10^{6}$ & $1.14 \pm 0.12 \times 10^{6}$ & 0.9648 \\
\hline Reported value & $8.04 \times 10^{3}$ & $2.07 \times 10^{3}$ & $1.97 \times 10^{3}$ & $1.53 \times 10^{5}$ & $2.19 \times 10^{4}$ & 0.9730 \\
\hline
\end{tabular}


wavelength was observed. The respective spectra of free hydrazone ligands 1, 2, 3 and complexes 4, 5 and $\mathbf{6}$ are given in Fig. S9, S10† and 8. At the same time, the tryptophan fluorescence emission showed significant decrease in the intensity (at $342 \mathrm{~nm}$ ) of about $35.27,40.54,46.08,52.16,66.71$ and $70.45 \%$, without any change in the position of the emission band. These experimental results indicate that the metal complexes did affect microenvironments of both tyrosine and tryptophan residues during the binding process. Hence, during the binding process the polarity around the tyrosine and tryptophan residues were decreased and the hydrophobicity around the same residues was strengthened, however, the effect was more towards tryptophan than tyrosine. The hydrophobicity observed in fluorescence and synchronous measurements confirmed the effective binding of all the complexes with the BSA and these results are comparable with earlier reports. ${ }^{57}$

\section{Antioxidant activities}

In order to elucidate the ability of the nickel hydrazone complexes to act toward different reactive radical species, we tested some radical scavenging assay methods, in particular superoxide $\left(\mathrm{O}_{2}{ }^{-}\right)$, hydroxyl $(\mathrm{OH})$ and nitric oxide $(\mathrm{NO})$ radical scavenging assays. The hydrazone ligands and their metal complexes have been tested in the range of $10-50 \mu \mathrm{M}$ concentrations. The free radical scavenger action is very important especially in the case of superoxide anion, since it prevents or attenuates the formation of peroxynitrite and hydroxyl radical. The over production of peroxynitrite and hydroxyl radical is an important feature of tissue damage mechanisms during pathological processes. ${ }^{57}$ In this regard, the antioxidant potentials against superoxide $\left(\mathrm{O}_{2}{ }^{-}\right)$ by the tested complexes were gave the $\mathrm{IC}_{50}$ values: $33.28 \pm$ $0.52,30.84 \pm 0.70$ and $23.11 \pm 0.42 \mu \mathrm{M}$ respectively for complexes 4-6 (Fig. 9), however the free hydrazone ligands do not show significant activity against the same radical under identical experimental conditions.

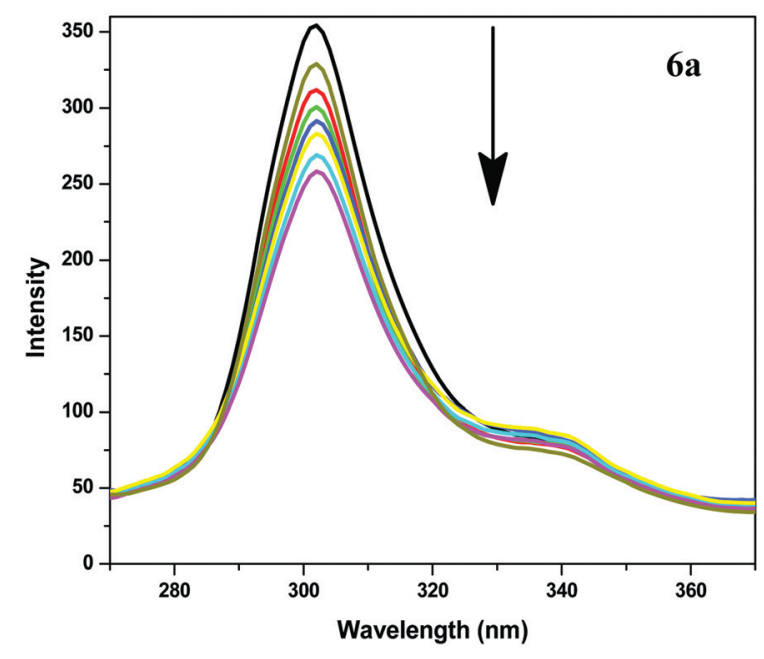

The hydroxyl radical is one of the most aggressive oxidants known which is capable of attacking any biological molecule. It is a major product arising from the high-energy ionisation of water and its most important biological source is the HaberWeiss and Fenton reaction, involving superoxide anion, hydrogen peroxide and transition metals. Hydroxyl radical is highly reactive oxygen centered radical formed from the reactions of various hydroperoxides with transition metal ions. Among all the free radicals, hydroxyl radical is by far the most potent and therefore the most dangerous oxygen metabolite and hence the elimination of this radical is one of the major aims of antioxidant administration. ${ }^{58}$ It attacks proteins, DNA, polyunsaturated fatty acid in membranes and most biological molecules. ${ }^{59}$ Hydroxyl radical is known to be capable of abstracting hydrogen atoms from membrane lipids and brings about the peroxidic reaction of lipids. The scavenging activity of the nickel hydrazones on the hydroxyl radical has been investigated and their inhibitory effect on the $\mathrm{OH}$ radical is shown in Fig. 9. The $\mathrm{IC}_{50}$ values of nickel hydrazone complexes 4-6 are found to be $35.92 \pm 0.33,33.61 \pm$ 0.54 and $29.99 \pm 0.73 \mu \mathrm{M}$ respectively. Further, the free hydrazone ligands 1-3 failed to arrest the above said free radicals under the studied concentration range.

Nitric oxide (NO) is a diffusible free radical which plays a role as an effector in diverse biological systems including neuronal messenger, vasodilatation and antimicrobial and antitumor activities. ${ }^{60}$ Nitric oxide inhibitors were shown to have beneficial effects on some aspect of inflammation and tissue damage seen in inflammatory diseases. ${ }^{61}$ These compounds are responsible for altering both the structural and functional behaviour of many cellular components. The metal hydrazones have the property to counteract the effect of NO formation and in turn possess considerable interest in preventing the ill effects of excessive NO generation in the human body. In order to understand the ability of the nickel hydrazone complexes towards the reactive radical species, a NO scavenging assay of them was carried out at different concentration of complexes and the results are presented in Fig. 9, and the corresponding $\mathrm{IC}_{50}$ values of the hydrazone

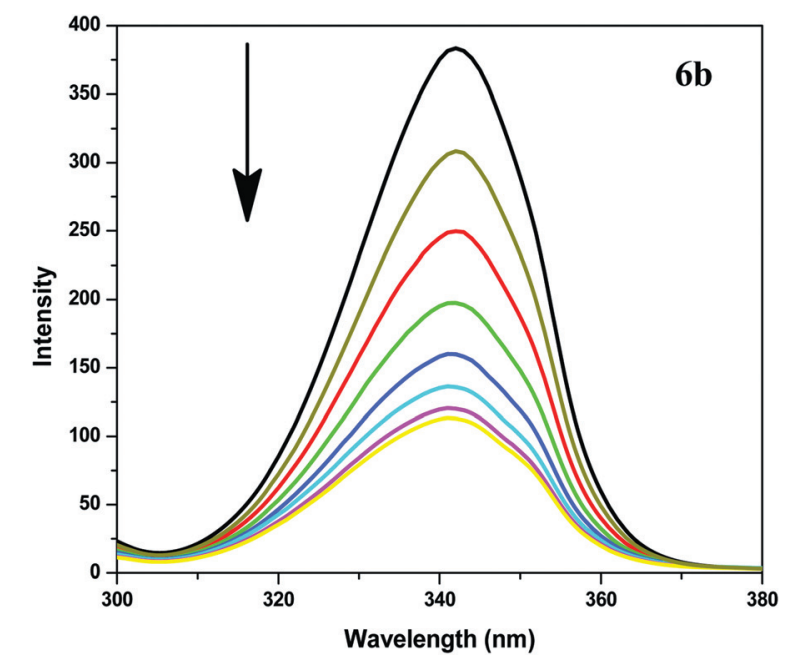

Fig. 8 Synchronous spectra of BSA $\left(1 \times 10^{-6} \mathrm{M}\right)$ as a function of concentration of the complex $6\left(0,2,4,6,8,10,12\right.$ and $\left.14 \times 10^{-7} \mathrm{M}\right)$ with a wavelength difference of $\Delta \lambda=15 \mathrm{~nm}$ (a) and $\Delta \lambda=60 \mathrm{~nm}$ (b). Arrow indicates the change in emission intensity w.r.t. various concentration of complex. 

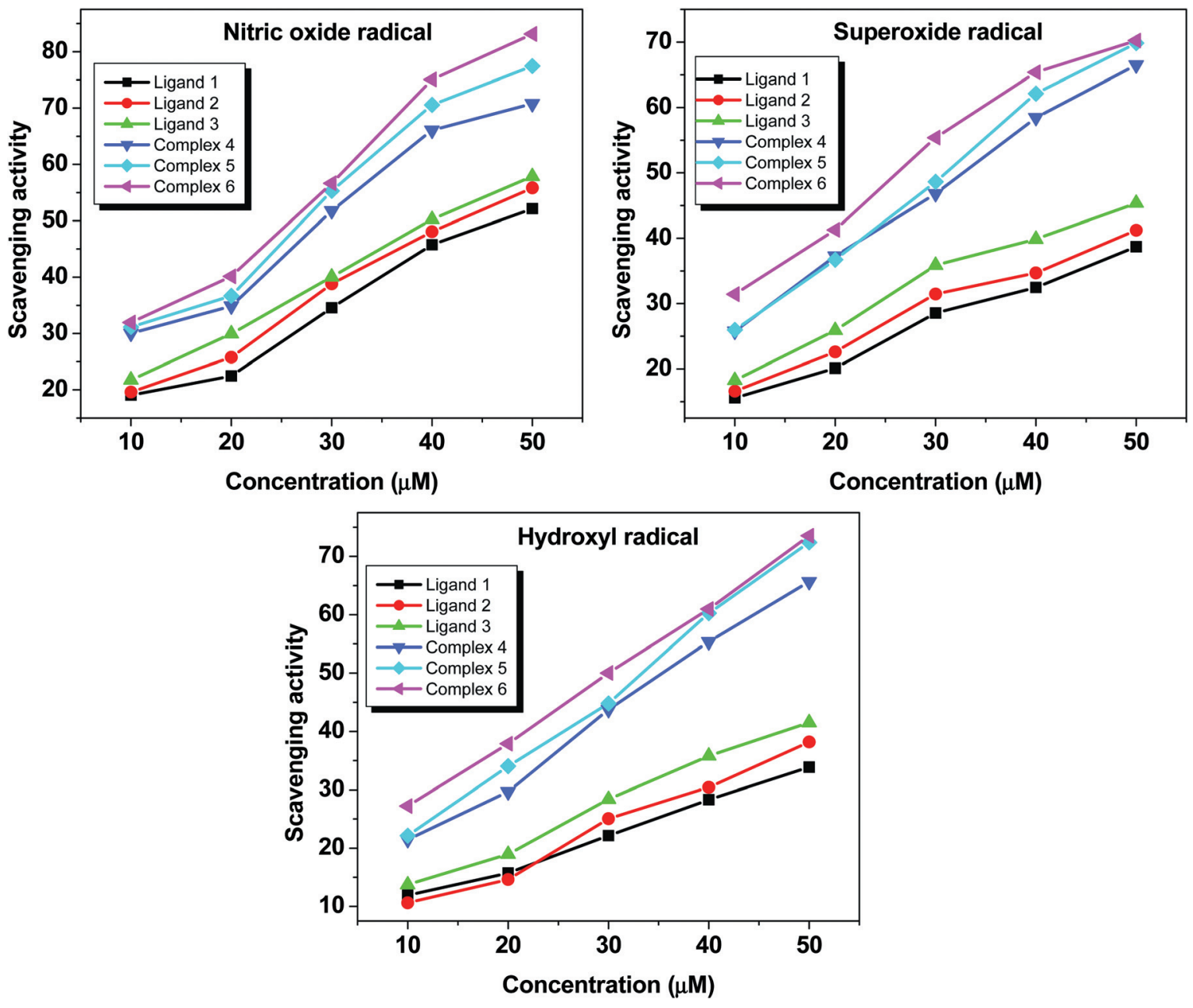

Fig. 9 Trends in the inhibition of super oxide, hydroxyl and nitric oxide radicals by synthesised compounds 1-6 at variable concentrations.

ligands $\mathbf{1} \mathbf{- 3}$ and its metal complexes $\mathbf{4} \mathbf{- 6}$ are $46.74 \pm 0.87,42.51$ $\pm 0.29,39.97 \pm 0.54,28.43 \pm 0.30,27.05 \pm 0.91$ and $25.72 \pm$ 0.38 . However, the nickel precursor complex did not register any scavenging potentials under the same experimental conditions. The antioxidant properties of the hydrazone ligands and its nickel(II) complexes studied towards the above said radicals were compared with standard antioxidant butylated hydroxy anisole (BHA).

Fig. 9 shows the plot of the hydroxyl radical scavenging effect (\%) and it is found that the inhibitory effect of the compounds tested with $\mathrm{O}_{2}{ }^{-}, \mathrm{OH}$ and $\mathrm{NO}$ radicals are concentration dependent and their suppression ratio increases with increasing sample concentrations in the tested range. From the above values (Table 5), it is found that all the metal complexes tested in this study behaved as more effective inhibitors than the standard scavenging agent, butylated hydroxy anisole (BHA) for $\mathrm{O}_{2}{ }^{-}, \mathrm{OH}$ and NO radicals and are compared with that of the other nickel complexes. $^{53,62}$

In general, the antioxidant activity of synthesised compounds against the free radicals $\mathrm{O}_{2}{ }^{-}, \mathrm{OH}$ and $\mathrm{NO}$ decreased in the order $\mathbf{6}>\mathbf{5}>\mathbf{4}>\mathbf{3}>\mathbf{2}>\mathbf{1}$. Among all three nickel hydrazones, the one possessing six membered pyridine ring in the hydrazone moiety (complex 6) showed more potential scavenging activity
Table 5 Comparison of $\mathrm{IC}_{50}$ values of test compounds towards selected free radicals

\begin{tabular}{llll}
\hline & \multicolumn{2}{l}{$\mathrm{IC}_{50}$ values $(\mu \mathrm{M})$} & \\
\cline { 2 - 4 } $\begin{array}{l}\text { Test } \\
\text { compounds }\end{array}$ & $\begin{array}{l}\text { Superoxide } \\
\text { radical }\end{array}$ & $\begin{array}{l}\text { Hydroxyl } \\
\text { radical }\end{array}$ & $\begin{array}{l}\text { Nitric oxide } \\
\text { radical }\end{array}$ \\
\hline $\mathbf{1}$ & - & - & $46.74 \pm 0.87$ \\
$\mathbf{2}$ & - & - & $42.51 \pm 0.29$ \\
$\mathbf{3}$ & - & - & $39.97 \pm 0.54$ \\
$\mathbf{4}$ & $33.28 \pm 0.52$ & $35.92 \pm 0.33$ & $28.43 \pm 0.30$ \\
$\mathbf{5}$ & $30.84 \pm 0.70$ & $33.61 \pm 0.54$ & $27.05 \pm 0.91$ \\
$\mathbf{6}$ & $23.11 \pm 0.42$ & $29.99 \pm 0.73$ & $25.72 \pm 0.38$ \\
Reported value & 4 & 38.46 & 10.11 \\
\hline
\end{tabular}

than the rest of the complexes with five membered furan and thiophene rings in the complexes $\mathbf{4}$ and $\mathbf{5}$. Further, the nickel hydrazone complexes exhibited better activity when compared to that of free hydrazone ligands which might be due to the chelate effect. Hence, we strongly believe that the present metal hydrazone complexes can be further evaluated as suitable candidates leading to the development of new potential antioxidants and therapeutic reagents for some diseases. 
Table 6 Comparison of $\mathrm{IC}_{50}$ values between complexes 4-6

\begin{tabular}{lllll}
\hline \multirow{5}{*}{ Complex } & \multicolumn{4}{l}{$\mathrm{IC}_{50}$ values in $\mu \mathrm{M}$} \\
\cline { 2 - 5 } & HeLa & HepG-2 & A431 & NIH 3T3 \\
\hline $\mathbf{4}$ & $185.6 \pm 1.6$ & $115.3 \pm 1.3$ & $45.7 \pm 0.9$ & $481.7 \pm 2.4$ \\
$\mathbf{5}$ & $125.9 \pm 0.9$ & $88.2 \pm 1.2$ & $29.3 \pm 1.1$ & $456.6 \pm 1.8$ \\
$\mathbf{6}$ & $116.6 \pm 0.7$ & $50.9 \pm 0.8$ & $19.1 \pm 0.5$ & $407.1 \pm 1.5$ \\
Reported value & 92.86 & - & 80.72 & 312.44 \\
Reported value & 49.48 & - & 35.13 & 188.53 \\
\hline
\end{tabular}

\section{Cytotoxicity}

The cytotoxicity of the synthesised ligands $\mathbf{1}-\mathbf{3}$, the starting precursor complex $\left[\mathrm{NiCl}_{2}\left(\mathrm{PPh}_{3}\right)_{2}\right]$ and their hydrazone complexes 4-6 was tested with a MTT colorimetric assay that measures mitochondrial dehydrogenase activity as an indication of cell viability against HeLa (human cervical cancer cells), A431 (human skin cancer cells), HepG2 (human liver hepatocellular carcinoma cells) and normal NIH 3T3 (mouse embryonic cells). The test compounds were dissolved in DMSO and blank samples containing the same amount of DMSO are taken as controls. The effects of the compounds on the viability of these cells were evaluated after an exposure period of $48 \mathrm{~h}$. All the complexes showed very good cytotoxic potencies under the studied concentrations with the inhibition of cancer cell growth at the $50 \%$ level.

Assays of nickel hydrazones against cancerous cell lines HeLa, HepG-2 and NIH 3 T3 normal cell lines were performed in the concentration range of 15 to $500 \mu \mathrm{M}$ whereas A431 cell lines were performed in the concentration range of 6.25-200 for complexes 4 and $\mathbf{5}$ and 3.12-100 $\mu \mathrm{M}$ for complex $\mathbf{6}$. Among the cancerous cell lines, the $\mathrm{IC}_{50}$ values of the investigated complexes 4-6 against A431 are found to be low which indicates its higher activity when compared to that of the other cancerous cell lines HeLa and HepG2 with high $\mathrm{IC}_{50}$ values (Table 6) (Fig. S11†). All the complexes did not cause any damage to the healthy cells (NIH 3T3) indicating that they are non-toxic to normal cells as expected for a better drug. On comparison with that of the other reported nickel hydrazone complexes ${ }^{63}$ our complexes showed better activity and the same was included in Table 6. However, the hydrazone ligands 1-3 and the nickel precursor complex did not show any activity under the same experimental conditions. Cisplatin was used as a standard to assess the cytotoxicity of complexes 4, 5 and $\mathbf{6}$ (not shown in graph).

Comparison of the anticancer activity of nickel hydrazone complexes reveal that upon changing the hydrazide moieties the activity of the complexes gets varied. Furthermore, the most promising compound in the series is complex $\mathbf{6}$ containing the six membered pyridine ring. These observations do indicate that varying the size of heterocyclic ring attached to the hydrazide moiety from five membered to six membered ring and also the electronegativity of the heteroatom present in it resulted in a concomitant increase in the anticancer activity of the complexes.

\section{Conclusion}

In this work, the synthesis of three new nickel(II) complexes containing binegative tridentate ONO chelating hydrazone ligands and their interaction with biomolecules were presented. The structure and geometry of the complexes analysed through single crystal X-ray diffraction revealed a square planar geometry around the $\mathrm{Ni}$ (II) ion in complexes $\mathbf{4}$ and $\mathbf{5}$. From the bioinorganic chemistry point of view, the binding interaction of the synthesised compounds 1-6 with CT DNA and BSA protein has been investigated and the order of binding affinity varies from a magnitude of $10^{2}$ to $10^{5}$. Also, their antioxidant and cytotoxicity properties showed that they can be studied as potential drugs. To summarise, complex 6 that possess a pyridine ring with delocalized $6 \pi$ electrons at the hydrazide part showed a better performance in biomolecular interactions than the other two complexes $\mathbf{4}$ and $\mathbf{5}$ that have five membered heterocyclic rings. But, among the complexes $\mathbf{4}$ and $\mathbf{5}$ with five membered heterocyclic moieties, the former one with the more electronegative oxygen atom displayed less potential with regard to biomolecular interactions and cytotoxicity than the later one with a sulphur atom that could have favoured the formation of an electron rich environment around the central nickel ion and thus led to a better interaction with the biomolecules.

\section{Acknowledgements}

We sincerely thank the University Grants Commission, New Delhi for the award of a Fellowship in Science for Meritorious Students (RFSMS) to one of the authors (P. Krishnamoorthy) under the UGC-SAP-DRS programme. AHC is grateful to the Robert A. Welch Foundation (Grant F-0003) for financial support of this work.

\section{References}

1 R. K. Andrews, R. L. Blakeley and B. Zerner, in Metal Ions in Biological Systems, ed. H. Sigel and A. Sigel, Marcel Dekker, New York, 1988, pp. 165-284.

2 M. A. Halcrow and G. Christou, Chem. Rev., 1994, 94, 2421-2481.

3 F. Meyer and H. Kozlowski, in Comprehensive Coordination Chemistry II, ed. J. A. McCleverty and T. J. Meyer, Elsevier, 2003, vol. 6, pp. 247-554.

4 P. Bombicz, E. Forizs, J. Madarasz, A. Deak and A. Kalman, Inorg. Chim. Acta, 2001, 315, 229-235.

5 G. Morgant, N. Bouhmaida, L. Balde, N. E. Ghermani and J. d'Angelo, Polyhedron, 2006, 25, 2229-2235.

6 O. Z. Yesilel, M. S. Soylu, H. Olmez and O. Buyukgungor, Polyhedron, 2006, 25, 2985-2992.

7 N. C. Kasuga, K. Sekino, C. Koumo, N. Shimada, M. Ishikawa and K. Nomiya, J. Inorg. Biochem., 2001, 84, 55-65.

8 M. Alexiou, I. Tsivikas, C. Dendrinou-Samara, A. A. Pantazaki, P. Trikalitis, N. Lalioti, D. A. Kyriakidis and D. P. Kessissoglou, J. Inorg. Biochem., 2003, 93, 256-264.

9 R. Kurtaran, L. T. Yildirim, A. D. Azaz, H. Namli and O. Atakol, J. Inorg. Biochem., 2005, 99, 1937-1944.

10 R. del Campo, J. J. Criado, E. Garcia, M. R. Hermosa, A. JimenezSanchez, J. L. Manzano, E. Monte, E. Rodriguez-Fernandez and F. Sanz, J. Inorg. Biochem., 2002, 89, 74-82.

11 E. M. Jouad, G. Larcher, M. Allain, A. Riou, G. M. Bouet, M. A. Khan and X. D. Thanh, J. Inorg. Biochem., 2001, 86, 565-571.

12 W. Luo, X. Meng, X. Sun, F. Xiao, J. Shen, Y. Zhou, G. Cheng and Z. Ji, Inorg. Chem. Commun., 2007, 10, 1351-1354.

13 Z. Afrasiabi, E. Sinn, W. Lin, Y. Ma, C. Campana and S. Padhye, J. Inorg. Biochem., 2005, 99, 1526-1531.

14 M. C. Rodriguez-Arguelles, M. Belicchi Ferrari, F. Bisceglie, C. Pelizzi, G. Pelosi, S. Pinelli and M. Sassi, J. Inorg. Biochem., 2004, 98, $313-$ 321. 
15 J. Garcia-Tojal, J. L. Pizarro, A. Garcia-Orad, A. R. Perez-Sanz, M. Ugalde, A. A. Diaz, J. L. Serra, M. I. Arriortua and T. Rojo, J. Inorg. Biochem., 2001, 86, 627-633.

16 A. Buschini, S. Pinelli, C. Pellacani, F. Giordani, M. B. Ferrari, F. Bisceglie, M. Giannetto, G. Pelosi and P. Tarasconi, J. Inorg. Biochem., 2009, 103, 666-677.

17 M. Katual and G. Dutt, Talanta, 1975, 22, 151-166.

18 B. Singh, R. Shrivastava and K. K. Narang, Synth. React. Inorg. Met.Org. Chem., 2000, 30, 1175-1192.

19 K. C. Skyrianou, C. P. Raptopoulou, V. Psycharis, D. P. Kessissoglou and G. Psomas, Polyhedron, 2009, 28, 3265-3271.

20 K. C. Skyrianou, E. K. Efthimiadou, V. Psycharis, A. Terzis, D. P. Kessissoglou and G. Psomas, J. Inorg. Biochem., 2009, 103, 16171625.

21 K. C. Skyrianou, F. Perdih, I. Turel, D. P. Kessissoglou and G. Psomas, J. Inorg. Biochem., 2010, 104, 161-170.

22 Y. Jin, M. A. Lewis, N. H. Gokhale, E. C. Long and J. A. Cowan, J. Am. Chem. Soc., 2007, 129, 8353-8361.

23 N. G. A. Abrescia, L. Malinina, L. G. Fernandez, T. Huynh-Dinh, S. Neidle and J. A. Subirana, Nucleic Acids Res., 1999, 27, 1593-1599.

24 G. Barone, N. Gambino, A. Ruggirello, A. Silvestri, A. Terenzi and V. T. Liveri, J. Inorg. Biochem., 2009, 103, 731-737.

25 S. S. Matkar, L. A. Wrischnik, P. R. Jones and U. Hellmann-Blumberg, Biochem. Biophys. Res. Commun., 2006, 343, 754-761.

26 Y. P. Wang, Y. L. Wei and C. Dong, J. Photochem. Photobiol., A, 2006, $177,6-11$.

27 J. N. Tian, J. Q. Liu, Z. D. Hu and X. G. Chen, Bioorg. Med. Chem., 2005, 13, 4124-4129.

28 L. B. Qu, X. L. Chen, R. Yang, L. Wang and H. J. Zeng, Chin. J. Chem., 2007, 25, 1151-1155.

29 Y. J. Hu, H. G. Yu, J. X. Dong, X. Yang and Y. Liu, Spectrochim. Acta, Part A, 2006, 65, 988-992.

30 J. Venanzi, J. Chem. Soc., 1958, 719-724.

31 G. M. Sheldrick, Acta Crystallogr., Sect. A: Found. Crystallogr., 2008, A64, 112-122.

32 A. L. Spek, Acta Crystallogr., Sect. D: Biol. Crystallogr., 2009, D65, $148-155$.

33 J. Marmur, J. Mol. Biol., 1961, 3, 208-218.

34 M. E. Reichmann, S. A. Rice, C. A. Thomas and P. Doty, J. Am. Chem. Soc., 1954, 76, 3047-3053.

35 A. Wolfe, G. H. Shimer and T. Meehan, Biochemistry, 1987, 26, 63926396.

36 M. Lee, A. L. Rhodes, M. D. Wyatt, S. Forrow and J. A. Hartley, Biochemistry, 1993, 32, 4237-4245.

37 C. Beauchamp and I. Fridovich, Anal. Biochem., 1971, 44, 276-287.

38 T. Nash, Biochem. J., 1953, 55, 416-421.
39 L. C. Green, D. A. Wagner, J. Glogowski, P. L. Skipper, J. S. Wishnok and S. R. Tannenbaum, Anal. Biochem., 1982, 126, 131-138.

40 M. Blagosklonny and W. S. EI-diery, Int. J. Cancer, 1996, 67, 386-392.

41 K. Chichak, U. Jacquemard and N. R. Branda, Eur. J. Inorg. Chem., 2002, 357-368.

42 T. Ghosh, B. Mondal, T. Ghosh, M. Sutradhar, G. Mukherjee and M. G. B. Drew, Inorg. Chim. Acta, 2007, 360, 1753-1761.

43 M. Kandaz, I. Yilmaz, S. Keskin and A. Koca, Polyhedron, 2002, 21, 825-834.

44 P. Sathyadevi, P. Krishnamoorthy, R. R. Butorac, A. H. Cowley, N. S. P. Bhuvanesh and N. Dharmaraj, Dalton Trans., 2011, 40, 9690-9702.

45 W. J. Mei, J. Liu, H. Chao, L. N. Ji, A. X. Li and J. Z. Liu, Transition Met. Chem., 2003, 28, 852-857.

46 G. Y. Bai, K. Z. Wang, Z. M. Duan and L. H. Gao, J. Inorg. Biochem., 2004, 98, 1017-1022.

47 G. Han and P. Yang, J. Inorg. Biochem., 2002, 91, 230-236.

48 P. Krishnamoorthy, P. Sathyadevi, K. Senthil Kumar, P. Thomas Muthiah, R. Ramesh and N. Dharmaraj, Inorg. Chem. Commun., 2011, 14, 1318 1322.

49 D. Senthil Raja, G. Paramaguru, N. S. P. Bhuvanesh, J. H. Reibenspies, R. Renganathan and K. Natarajan, Dalton Trans., 2011, 40, 4548-4559.

50 P. Krishnamoorthy, P. Sathyadevi, A. H. Cowley, R. R. Butorac and N. Dharmaraj, Eur. J. Med. Chem., 2011, 46, 3376-3387.

51 D. S. Raja, N. S. P. Bhuvanesh and K. Natarajan, JBIC, J. Biol. Inorg. Chem., 2012, 17, 223-237.

52 S. S. Wu, W. B. Yuan, H. Y. Wang, Q. Zhang, M. Liu and K. B. Yu, J. Inorg. Biochem., 2008, 102, 2026-2034.

53 P. Sathyadevi, P. Krishnamoorthy, E. Jayanthi, R. R. Butorac, A. H. Cowley and N. Dharmaraj, Inorg. Chim. Acta, 2012, 384, 83-96.

54 G. Z. Chen, X. Z. Huang, Z. Z. Zheng, J. G. Xu and Z. B. Wang, Analysis Method of Fluorescence, Science Press, Beijing, 3rd edn, 1990.

55 J. N. Miller, Proc. Anal. Div. Chem. Soc., 1979, 16, 203-208.

56 J. H. Tang, F. Luan and X. G. Chen, Bioorg. Med. Chem., 2006, 149, 3210-3217.

57 J. M. C. Gutteridge, Chem.-Biol. Interact., 1994, 91, 133-140.

58 N. Udilova, A. V. Kozlov, W. Bieberschulte, K. Frei, K. Ehrenberger and H. Nohl, Biochem. Pharmacol., 2003, 65, 59-65.

59 OI Aruoma, Asia Pac. J. Clin. Nutr., 1999, 8, 53-63.

60 M. J. Miller, H. Sadowska-Krowicka, S. Chotinaruemol, J. L. Kakkis and D. A. Clark, J. Pharmacol. Exp. Ther., 1993, 264, 11-16.

61 S. Moncada and A. Higgs, N. Engl. J. Med., 1993, 329, 2002-2012.

62 Zeng-Chen Liu, Bao-Dui Wang, Zheng-Yin Yang, Yong Li, Dong-Dong Qin and Tian-Rong Li, Eur. J. Med. Chem., 2009, 44, 44774484 .

63 P. Krishnamoorthy, P. Sathyadevi, R. R. Butorac, A. H. Cowley, N. S. P. Bhuvanesh and N. Dharmaraj, Dalton Trans., 2012, 41, 4423-4436. 